Article

\title{
Strategic Alliances in Firm-Centric and Collective Contexts: Implications for Indigenous Entrepreneurship
}

\author{
Antony I. Jongwe ${ }^{1}$, Peter W. Moroz ${ }^{2}$, Moses Gordon ${ }^{3}$ and Robert B. Anderson ${ }^{2, *}$ \\ 1 School of Business and Governance, North West University, Private Bag X6001, Potchefstroom 2520, \\ South Africa; antonyjongwe@yahoo.com \\ 2 Hill/Levene Schools of Business, University of Regina, 3737 Wascana Parkway, Regina, SK V4A6X3, Canada; \\ peter.moroz@uregina.ca \\ 3 School of Business and Public Administration, First Nations University of Canada, 1 First Nations Way, \\ Regina, SK S4S7K2, Canada; mgordon@firstnationsuniversity.ca \\ * Correspondence: robert.anderson@uregina.ca
}

Received: 21 October 2019; Accepted: 9 April 2020; Published: 15 April 2020

\begin{abstract}
How might diverse and often conflicting knowledge and belief structures and practices be mobilized into legitimate approaches for people looking to address the need for heightened responsible and sustainable entrepreneurial action by business organizations; humanizing the role of business in development? To answer this question, we explore two previously unconnected but aligned streams of literature: (i) work on strategic business alliances in general (R1); and (ii) work on corporate/Indigenous community partnerships specifically (R2). A systematic literature search identified 300 papers on the topics in total. We selected 39 general and 23 Indigenous-specific papers for review using a guiding classification matrix to determine principal themes and concepts. Both streams of literature were reviewed, and an approach was developed to identify areas where the empirical observation of Indigenous partnerships provides a contribution to the theory and practice of Indigenous entrepreneurship within the realm of strategic alliance formation, and vice versa. The paper concludes with a discussion of dissimilarities in the two streams of literature and maps out avenues for future research into strategic alliances involving corporate responsibility and sustainability (CRS), approaches based on Indigenous belief and value systems, and Indigenous entrepreneurship.
\end{abstract}

Keywords: indigenous people; entrepreneurship; sustainable development; strategic alliances; corporate responsibility and sustainability

\section{Introduction}

Recent broader societal and political developments and their impact on organizational practices raise the question of whether the dominant neoliberal capitalist system poses important constraints on corporate actions that engender and encourage negative ethical, social, and environmental externalities of business conduct. This has given rise to corporate responsibility and sustainability (CRS), which is both an interdisciplinary study of how companies construct and enact entangled responsibility-sustainability (Laasch 2016) and a voluntary strategic approach by business to forestall and prevent further regulation of 'free' markets and curtailments of the extent of private property rights (Porter and Kramer 2011; Barton 2011).

CRS is a subset of organizational phenomena which can be viewed through an Indigenous entrepreneurship lens (Swinney 2008; Matten and Moon 2008). Managers seeking to implement CRS measures into organizational activities long dealt with the pressure to pursue and achieve optimal outcomes (Porter and Kramer 2011; Rost and Ehrmann 2015). This drive for business to be both 
productive, profit making, and socially and environmentally responsible has not yet met the challenge of making CRS positively and empirically transformative (Wickert et al. 2016; Short et al. 2016) or even reliably viable from a financial perspective (Margolis and Walsh 2003; Galbreath and Shum 2012; Kang et al. 2016; Wang et al. 2016). Exploring this, scholars have suggested that for a traditional entrepreneurship system to more effectively regulate itself in the pursuit of profit, it must 'emerge out of the contingent processes of struggle' by not consistently relying on existing entrepreneurial structures, norms and processes (Himley 2013, p. 397; Peredo et al. 2017; Pirson 2017).

Business organizations need to move beyond the regulatory imperatives of institutional and firm-based incentives to actively engage in the 'mutual shaping' of CRS with and within dynamic local systems to make them meaningful (Campbell 2007; Matten and Moon 2008). It is within these local, often culturally distinctive, contexts where groups, communities, and forms of organizing may socially regulate behavior to shape the trajectory of capitalism through the process of corporations 'taking on' norms from other systems of values, beliefs, and even epistemologies (de los Reyes et al. 2017; Tickell and Peck 1996); a more collective approach to management (Pirson 2017). The extent to which this alteration happens provides part of the answer to the question: "Enrolling the private sector in community development: magic bullet or sleight of hand?" raised by McEwan et al. (2017). Our work suggests a continuum of possible outcomes between these perspectives of human nature (individualistic versus collective), which emerge as a result of the values, goals, actions, and capacities of the parties involved (Pirson 2017).

In order to address the problem of incorporating new and potentially conflicting collective approaches into typically firm-centric perspectives on organizational CRS (Pirson 2017), we explore the similarities and differences between two streams of literature; that is, work on corporate strategic alliances (SAs) in general (Review 1 or R1) and work on corporate/community partnerships in an Indigenous context in particular (Review 2 or R2). Of late, alliances as a tool for collaboratively managing CRS strategies have proved to be a small but emergent topic of research in the discipline of management studies (for example, Brooks 2005; Husted 2003; Thorne et al. 2017; Warner and Sullivan 2017).

Yet few studies have focused on alliances as a way to enhance human dignity, shared value creation, and societal legitimacy through relationally engaging with culturally diverse stakeholders through partnerships (Pirson 2017; Le Ber and Branzei 2010; McDonald and Young 2012). As a relatively newly emerging body of research, the literature on Indigenous corporate/community alliances provides a unique and potentially useful collective perspective on the overarching subject of SAs. We feel this is especially relevant in enriching theory and practice pertaining to CRS. Therefore, the potential for engaging with approaches to SAs incorporating local (i.e., Indigenous) knowledge and belief structures and practices (O'Faircheallaigh and Ali 2008) may serve to increase the prospects of achieving elusive 'win-win' CRS outcomes.

The two streams of literature ( $\mathrm{R} 1$ and $\mathrm{R} 2$ ) differ in four fundamental ways. $\mathrm{R} 1$ is based primarily on business literature and uses the corporation as the unit of analysis, while R2 is more broadly social-science-based and focuses more on the Indigenous community and Indigenous approaches to SA. This literature (R2) takes into account the uniqueness of Indigenous identity and rights as recognized by the United Nations Declaration on the Rights of Indigenous People (UNDRIP) and most states as the basis of its epistemological worldview, predicated on the values and history of Indigenous people. In this sense, it is much closer to collective perspective (Pirson 2017). R1 adopts a worldview which resonates with the firm-centric perspective, with its focus on the organization as the most important driver of economic activity (Penrose and Penrose 1957) and pursuit of shareholder profit maximization. Further, R1 postulates that both parties (usually corporations) come together to form SAs 'willingly' in pursuit of shareholder value maximization, while in R2, they are often forced into shared-value creation arrangements (partnerships) that they otherwise would not consider because of Indigenous rights.

Indigenous peoples (we use the term 'Indigenous' throughout the paper, except when referring to specific Indigenous peoples, such as the Māori or the San; or constitutionally or otherwise recognized categories, such as the First Nations, Métis, and Inuit in Canada) are defined as distinct, self-identified groups and/or communities consisting of the original inhabitants of a given region that, as a result of 
occupation, conquest, or colonization, currently reside under the control of a dominant and culturally divergent polity. What is of key interest is that they remain holders of knowledge systems that are often locally specific, but broadly part of an ecological and collective worldview. This knowledge system and related practice are of great importance to the continuing survival of Indigenous individuals and communities as a unique and globally recognized category of distinct peoples (Nakashima and Roué 2002). These knowledge systems are not only considered as epistemologically divergent to firm-centric systems, but also on par to a science of 'cultural ecology and spiritualism' that epitomizes a set of collective and Indigenous knowledge systems and worldviews by which to govern local actions and behaviors amongst individuals, groups, and the planet itself. These systems thus contrast greatly with the firm-centric perspective of capitalism, while maintaining some parallels with the collective perspective (Pirson 2017).

Indigenous knowledge systems and worldviews feature highly in the partnerships that they develop (Anderson 1997) and it has been noted that there are curious aspects of complementariness with firm-centric systems, warranting further investigation (Berkes 1999; Levi-Strauss 1962; Sahlins 1972). Therefore, the comparison of R1 and R2 is rationalized by the need to explore the "counter hegemonic possibilities" that reside in the ongoing dynamism within partnerships among people with potentially conflicting worldviews and value systems (Horowitz 2014). What we do not know is whether R1 may inform upon this phenomenon to help understand and formulate success in these types of partnerships. The comparison of these streams of literature is also driven by a need for identifying how new approaches incorporating local (i.e., Indigenous) knowledge and belief structures and practices to SAs (and beyond, society) through the building of cross cultural relationships for achieving multiple objectives in sync with the collective paradigm (Ackers 2015; Nicholson et al. 2017; Senevirathna 2018).

Collective frameworks are steeped in Indigenous entrepreneurship, which is an alternative paradigm for management. The collective paradigm is an alternative worldview to the current firm-centric paradigm which focuses on wealth acquisition, which situates people and the promotion of their wellbeing and dignity rather than mere wealth. Collective frameworks may thus be defined as an epistemology predicated on two questions: 'Who are people? And how can we organize to create a world that works for all or a life-conducive economic system' (Pirson 2017). An understanding of "who we are as people" influences how we organize individually, in groups, in organizations, and in society.

Going forward, the Indigenous knowledge systems and worldviews will be used to denote approaches incorporating local (i.e., Indigenous) knowledge and belief structures and practices, defined as theory (such as deontology or utilitarianism), or epistemology (a specific way to interpret the world around you), that make up an individual's, group's, and/or society's set of values that are culturally distinct and stable across long periods of time (see Henry and Pene 2001; de los Reyes et al. 2017). As Indigenous epistemological systems have been positioned as a competing paradigm with the firm-centric paradigm, it serves as a rich field for surveying and sampling divergent Indigenous knowledge systems and worldviews relevant to corporate actors and CRS, which stand in contrast to the regulation of the behavior of stakeholders by firms (Banerjee 2008).

Thus, we examine and compare how R1 and R2 may constructively inform each other. In doing so, we ask the question: how may SAs amongst corporations and Indigenous communities (and alloyed organizations) contribute to the development of Indigenous knowledge systems and worldviews for advancing the structure, efficacy, and legitimacy of responsible and sustainable efforts toward people and planet? Pursuant to this, we outline three interlinked research goals.

First, we seek to evaluate the theory, concepts, and practices relevant to the goals, best practices/strategies, and measured outcomes of both strands of literature. Our approach is to compare two different levels/types of social regulation that have yet to be systematically reviewed and contrasted: community-based (collective organizing advanced by Peredo and Chrisman 2006) vs. organizational-based (theory of the firm, advanced by Penrose and Penrose 1957). Second, we seek to evaluate points of similarity and identify what is distinct, if anything, between the two strands of literature.

This exercise will help develop theories of context that may better inform either phenomenon, while mapping out dissimilarities or differences from one to the other where applicable. Third, our 
contribution is intended to develop integrated Indigenous knowledge systems and worldviews to provide insight into how CRS practices may be improved through SAs with local communities to update and satiate a growing societal hunger for a more collective paradigm of management (Whetten 2009; Pirson 2017), which prioritizes human flourishing in all contexts.

The paper is structured as follows: first, we provide an overview of the research field that sets out the problem and a justification for the work entailed, placing it within the discourse of SAs, CRS, and Indigenous knowledge systems and worldviews. Next, we outline the systematic review process and content analysis methodology used for conducting the research. We then proceed to explain and justify the processes underpinning the selection, compilation, classification, and categorization of the two strands of literature. This is followed by a description of the analysis techniques used. We then compare the two approaches and present the findings using integrated Indigenous knowledge systems and worldviews (Glaser 1965).

\section{Theoretical Perspectives and Rationale}

Strategic alliances (SAs) are a well-researched, important, and growing area of academic inquiry within the overarching discipline of management (Vaidya 2011). They are generally defined as a voluntary partnership between two or more relatively independent organizations that are united to pursue some ongoing activity or process through an agreed upon governance structure (Albers et al. 2016; Gulati 1998; Stiles 2001). The decision to form an alliance is generally viewed as a long-term means for improving a company's competitive position in the marketplace through either a competencyor legitimacy-oriented focus (Lin and Darnall 2015). One of the reasons for the emergence of SAs as a compelling phenomenon for research is that properly constructed alliances are one of the key pathways for acquiring valuable resources necessary for ensuring the ongoing successful performance of member firms (Das and Teng 2000). The creation of successful alliances is highly dilemma prone due to the complexity of interfirm exchanges, alliance participants' perceptions of gains and losses, equity considerations, goal conflicts, and role ambiguities (Park and Ungson 2001).

Crucial to the urgency of our research, most of the extant literature on SAs is firm-centric and unidimensional in nature (Van Wijk et al. 2008). As capitalism shifts slowly to a more sensitive, inclusive, and collective paradigm, there is a need for expanding the alliance literature to include emerging forms of alliances that focus on different types of exchange philosophies, ethical and collective paradigms, and relationships that go beyond the current firm-centric unit of analysis (Harvey 2005). As part of this process, research into ethical, collective, and socially appropriate modes of production are gaining traction (Kayseas et al. 2017; Porter and Kramer 2011; Sabeti 2011; Shepherd and Patzelt 2011; Sukhdev 2012). This shift supports the move toward an alliance-based economy and greater importance of SAs between corporations and communities (Corbridge 1989). These new forms of SAs that engage partners other than for-profit firms, including governments and civil sector organizations, often do so for more than just economic reasons (Cordoba et al. 2017; Kopka et al. 2014). This observation has shifted study to new contextual and disciplinary vistas previously untapped, such as networks, communities, not-for-profit organizations, hybrid organizations, and Indigenous entrepreneurship (Quélin et al. 2017; Liu et al. 2016).

Focusing on this shift, there is a small but growing body of knowledge which utilizes Indigenous communities as a key unit of analysis to understand how alliances with non-Indigenous organizations could enable these communities to realize their overarching social, political, and economic goals (Anderson 1997; Anderson et al. 2006; Barker 2010; Hindle et al. 2005; Missens et al. 2007; Langton and Longbottom 2012; Moroz et al. 2014). Indigenous communities are observed to have a strong desire to participate in the global economy in a manner that is not disadvantageous to the attachment they place on cultural integrity, unique and varied heritages, value systems, as well as issues of autonomy/equality and nation-building (Anderson et al. 2006; Peredo et al. 2004).

At the same time as Indigenous communities are pursuing their development goals, corporations (particularly those in the natural resource industry) have viewed these alliances with Indigenous and other communities as a means for engaging in CRS, enhancing the legitimacy of sustainability 
and resource management policies/decisions, and mitigating reputational risk and license-to-operate concerns (McKenna 2015; Belal et al. 2013). Partnerships involving non-Indigenous communities and their institutions are fast becoming a tool that can address Indigenous development aspirations (Cornell and Kalt 2000; Coates and Crowley 2013; Swanson and Zhang 2015) and corporate CRS challenges. To address this growing need for knowledge on how corporations may devise pro-social and sustainable CRS strategies that are linked to long-term business sustainability, we focus on alliances that involve collective/community-based entities as increasingly significant participants in SAs. In particular, we consider community control over valuable tangible and intangible resources, ranging from natural and non-renewable resources to social licenses and human capital and legitimacy. In particular, we examine partnerships between corporations and Indigenous communities for three reasons.

First, Indigenous/corporate SAs are an area of research that is peripheral to the general management literature and is often relegated to non-mainstream areas of study across disciplines, such as economic development, geography, Indigenous studies, social policy, and environmental studies. Thus, there has been little cross-pollination or inclusion in mainstream management literature.

Second, there is an increasing interest from management scholars in developmental contexts because of the intersection of CRS initiatives with respect to the corporate interaction with residents and community-based groups impacted by their activities. Given the growing recognition of Indigenous people's relationship to natural and non-renewable resources globally, this is particularly significant to corporations involved in the extractive industries and other activities, which require access to contested Indigenous lands and resources (O'Faircheallaigh 2008; Barber and Jackson 2012; Anderson et al. 2006).

Third, the philosophies, value systems, and other distinct aspects of Indigenous communities differ from those dominant in the Western economic and political context. In addition to a sharp contrast in norms and values, Indigenous communities usually share a state of socioeconomic marginalization resulting from the impacts of colonization (Anderson 1997). This context results in a culturally-driven outlook and worldview, which permeates all aspects of Indigenous development initiatives. Unsurprisingly, findings associated with the body of literature on Indigenous alliances highlight community-driven enterprises with a focus on wider social goals, such as cultural revitalization, institution building, community development, and self-determination, in addition to, or primary to, profitability.

Expanding on the third point, Indigenous worldviews are akin in many ways to Indigenous knowledge systems and worldviews that may be applied in business and management research in that they may stand as a model for decision making based on an individual underlying moral predisposition as influenced by group membership as to how humans should interact with their ecosystems in pursuit of their wellbeing and dignity (Pirson 2017; Schminke and Wells 1999). They have also been shown to stand in contrast to the mainstream norms involving corporate and firm-centric interpretations of property rights and value systems - many Indigenous communities exhibit complex Indigenous knowledge systems and worldviews grounded in an alloy of common property rights systems within traditional and spiritual relationships among people and the land that are reinforced by a framework of inherent legal rights (Schlager and Ostrom 1992; Ridley-Duff and Bull 2011; Peredo et al. 2017; Runge 1986).

The collective paradigm is receiving interest in the academy as an emerging paradigm of economics and management that seeks to shift business strategy towards dignity and wellbeing that can benefit not only employees but society at large (Pirson 2017). It is a response to the business scandals, global social and environmental crisis, and public mistrust. It espouses the idea of human flourishing and reimagines twenty-first century business as communities (with responsibilities to stakeholders within and around those communities), rather than simply as a set of market-based contracts. As a result, and in line with other works in the domain of Indigenous entrepreneurship, profit maximization for shareholder value creation is not the only business driver and that, instead, businesses (as communities) have a role in advancing the common good and human flourishing.

Therefore, as enterprises continue to emerge around the world as a means for providing social benefits through participation and/or resisting the neoliberal market system (Rawhouser et al. 2015; 
Stiglitz 2002; Polanyi 1944), partnerships with Indigenous communities entail direct implications within the related spheres of CRS, Indigenous knowledge systems and worldviews, and SAs in theoretical and practical ways (Berkes and Ross 2013).

Thus, the focus of our research is to discover whether insights from R1 may have significance to the formation of partnerships between Indigenous and non-Indigenous organizations/communities under $\mathrm{R} 2$, as well as vice versa. More directly, we seek to evaluate whether the study of Indigenous/corporate alliances can offer insight into our understanding of the relationship among CRS and on Indigenous knowledge systems and worldviews for enhancing effectiveness and legitimacy through the comparison of SAs from a collective organizing and theory of the firm perspective. R2 is particularly interesting given the evolving nature of the global economy, the growing importance of both Indigenous entrepreneurship and CRS on one hand, and a complimentary alignment of broadly held sustainability goals with the Indigenous knowledge systems and worldviews of Indigenous peoples underpinned by their development objectives on the other.

The increasing recognition of Indigenous rights to traditional lands and resources with an emphasis on distinct forms of common property enterprises brings these potential alignments to the forefront of new intersections of study for those scholars working in the field of ethics and alliances. The potential overlap may also be important to mainstream management and entrepreneurship research, particularly to extractive and productive industries as well as other natural resource-based industries, such as fisheries, forestry, and renewable energy, where parts of Indigenous knowledge systems and worldviews are being acknowledged. It is in these contexts where neoliberal corporations confront divergent and often conflicting local modes of social regulation, including those of Indigenous communities.

\section{Methodology}

The study adopted a qualitative research design. Qualitative research is characterized by a wide variety of methods to choose from as there is no common template. Accordingly, qualitative researchers should be flexible and creative while applying some basic principles (Bansal and Corley 2011). This paper applied a varied set of qualitative methods involving review protocols, principal themes, and key concepts. As the SA literature is voluminous and varied across a wide range of categories, our approach was to draw forth theoretical and empirical evidence from a tactical systematic review of R1 and R2. In both reviews, we asked the question, "What are the key theories, types, objectives, best practices, and outcome measurements of strategic alliances?" Our objective was to produce an understanding of the types of SAs that exist, how the two strands of literature are similar, identify dissimilarities between them, and point to areas of distinction in each where one may inform the other. Patterns identified from the comparison of literature from both $\mathrm{R} 1$ and $\mathrm{R} 2$ were then used to guide future research on CRS, alliances, and Indigenous knowledge systems and worldviews, while informing upon theory improvement in cross-context scholarship, especially in the emerging Indigenous entrepreneurship theory (Whetten 2009).

\subsection{Review Protocols}

For the first stage of the comparative literature review, in line with Tranfield et al. (2003), the authors adopted a research protocol using an omnibus search or general summons, as shown in Table 1 . Confronted with the vastness of this literature, our strategy was to focus on key papers published between 2005 and 2015. However, an exception to the date rule was that seminal papers prior to this, as well as known eclectic papers, would also be considered. To identify the research pertaining to SAs in general contexts (R1), the authors created an initial protocol based on database scans for derivations of "strategic alliance" and "literature review" on ABI/INFORM, Wiley/Blackwell, and Emerald. The top 100 hits scan was conducted for each of the three databases to establish relevance in each, while eliminating for redundancies across each. Of the 100 articles looked at in each of the three databases, a total of 105 papers were selected for review after redundancies were eliminated. These were prioritized based on being: (a) literature reviews of SAs; (b) meta-analysis of the strategic 
alliance literature; and (c) highly cited models and/or frameworks distilled from theory or empirical data that inform important areas of enquiry on the key issues in SAs/partnerships. The final shortlist for analysis consisted of 30 papers with a further 9 from the seminal/eclectic collection. This resulted in a total of 39 papers out of the 300 for deeper review.

Table 1. Summary of the research protocol.

\begin{tabular}{|c|c|c|}
\hline Type of Literature Review & Selection I & rotocol \\
\hline $\begin{array}{l}\text { SA in General context: } \\
\text { 2005-2015 }\end{array}$ & $\begin{array}{l}\text { Keyword protocols/peer reviewed database(s) } \\
\text { "literature review" and "strategic alliances", } \\
\text { "joint ventures", "partnerships". }\end{array}$ & $\begin{array}{l}\text { Only peer reviewed literature reviews on } \\
\text { subject, meta-analysis, or heavily cited } \\
\text { theoretical papers against top } 20 \text { papers } \\
\text { per search, plus eclectic works known to } \\
\text { authors. }\end{array}$ \\
\hline $\begin{array}{l}\text { SA in Indigenous context: } \\
\qquad 2005-2015\end{array}$ & $\begin{array}{c}\text { Keyword protocols/peer/book chapters and } \\
\text { eclectic sources, top } 100 \text { (sorted by relevance) } \\
\text { "strategic alliance", "joint ventures", } \\
\text { "partnerships", "negotiated agreements" and } \\
\text { "Indigenous", "First Nations", "Aboriginal" } \\
\text { and "Native". }\end{array}$ & $\begin{array}{l}\text { Sort by definitions of Indigenous peoples } \\
\text { and include eclectic works known to } \\
\text { authors. }\end{array}$ \\
\hline
\end{tabular}

Source: Social Sciences and Humanities Research Council Project File.

For the second stage of the review that focused on Indigenous/corporate alliances (or R2), the authors created an initial protocol based on four database searches for "SAs" and "Aboriginal/First Nations/Indigenous/native" and another scan on 'types' of SAs using the search strings "joint ventures", "partnerships", and "negotiated agreements" referencing from ABI/INFORM, Economic Literature, Environmental Sciences, and Pollution Management, and Google Scholar. This index search was limited to full text, peer reviewed, and scholarly journals with a focus on business or business development. Following Hindle and Moroz (2010), the authors then cast a wider net using many search tools and contacts to locate journals and other outlets not represented in the main search engines. Journal and book editors were contacted to retrieve forthcoming chapters and papers not currently housed within accessible online databases. The authors also searched for theses and conference proceedings papers. The rationale for this selection design stems from the nascence and niche nature of the sub-field of Indigenous/corporate partnership (Kuhn 1970). The search yielded 87 articles that were deemed eligible for inclusion, of which 23 were found to be relevant to the objective of the research using criteria that satisfied the definition of Indigenous peoples as laid out in Hindle and Moroz (2010).

\subsection{Principal Themes and Key Concepts}

The authors began the classification task with an unfettered listing of prominent concepts, issues, and arguments derived or inferred from the papers reviewed. Following Hindle and Moroz (2010) and Lincoln and Guba (2004), the authors read each article, identified primary themes and concepts, and then sorted them into pre-conceived and agreed upon main categories corresponding to objectives/goals, processes/best practices, and measurement/outcomes. Additional descriptive secondary categories were provided that sought to: (1) apply a definition of SA type(s) the papers primarily covered; (2) theories used or developed from the paper; (3) the context of the SA; and (4) a category described as 'other' that sought to capture anything that did not fit into the categories as arranged. Two of the authors compared and discussed the data sorted into the primary coded categories until saturation and agreement was reached. The codings placed in each category were then analyzed to produce secondary codes and surface new ones through constant interaction over a period of 3 months. A similar coding process was adopted for both R1 and R2. The coding protocol mainly followed a reductionist strategy as set out in Denzin and Lincoln (2011), which sought to eliminate redundancies in the coding process, as shown in Table 2). For instance, no reported codes could be repeated, and different but alike codes were reported. The goal of the coding process was to build a framework for what the literature looks like based on our primary search parameters (objectives, process, and outcome measurements). 
Table 2. Coding protocol with partial coding for R1.

\begin{tabular}{|c|c|c|c|c|c|c|c|c|c|}
\hline & \multicolumn{9}{|c|}{ Primary Search Parameters } \\
\hline & \multicolumn{3}{|c|}{ Objectives } & \multicolumn{3}{|c|}{ Best Practices/Processes } & \multicolumn{3}{|c|}{ Outcome Measurements } \\
\hline & Primary Codes & Secondary Codes & Concept & $\begin{array}{l}\text { Primary } \\
\text { Codes }\end{array}$ & $\begin{array}{l}\text { Secondary } \\
\text { Code }\end{array}$ & Concept & $\begin{array}{l}\text { Primary } \\
\text { Codes }\end{array}$ & $\begin{array}{l}\text { Secondary } \\
\text { Code }\end{array}$ & Concept \\
\hline R1 & $\begin{array}{l}\text { Competitive edge } \\
\text { Increased flexibility } \\
\text { and productivity } \\
\text { Protect existing } \\
\text { markets } \\
\text { Means of gaining } \\
\text { competitive } \\
\text { advantage } \\
\text { Gain competitor } \\
\text { information } \\
\text { Raise barriers to } \\
\text { markets } \\
\text { Using existing } \\
\text { resources for future } \\
\text { expansion } \\
\text { To pursue new } \\
\text { strategic initiatives } \\
\text { such as entering a } \\
\text { new market } \\
\text { Accumulating } \\
\text { unique resources } \\
\text { for future use }\end{array}$ & $\begin{array}{l}\text { Competitive positioning } \\
\text { strategy } \\
\text { Legitimacy/meet } \\
\text { requirements } \\
\text { Growth and financial } \\
\text { returns } \\
\text { Access new } \\
\text { markets/internationalization } \\
\text { Access to knowledge and } \\
\text { learning processes } \\
\text { Capabilities/developing } \\
\text { dynamic capabilities } \\
\text { Efficient use of } \\
\text { resources/cost savings } \\
\text { Acquire } \\
\text { resources/resource } \\
\text { acquisitions } \\
\text { Productivity/new } \\
\text { opportunities } \\
\text { Supply chain } \\
\text { management } \\
\text { Reduce uncertainty }\end{array}$ & $\begin{array}{c} \\
\text { Competitive } \\
\text { Positioning }\end{array}$ & $\begin{array}{c}\text { Goal } \\
\text { compatibility } \\
\text { Synergy } \\
\text { among } \\
\text { partners } \\
\text { Avoiding } \\
\text { different } \\
\text { decision } \\
\text { making styles } \\
\text { Complimentary } \\
\text { assets and } \\
\text { needs } \\
\text { Compatible } \\
\text { goals }\end{array}$ & $\begin{array}{l}\text { Compatibility } \\
\text { of partners }\end{array}$ & $\begin{array}{c}\text { Partner } \\
\text { selection }\end{array}$ & $\begin{array}{c}\text { Financial } \\
\text { returns } \\
\text { Abnormal } \\
\text { returns } \\
\text { Increased } \\
\text { market share } \\
\text { Based on } \\
\text { external } \\
\text { evaluations }\end{array}$ & Financial & $\begin{array}{c}\text { Profit } \\
\text { maximization }\end{array}$ \\
\hline
\end{tabular}




\subsection{Strategic Alliances in General Context Review (R1)}

The bulk of the papers reviewed were conceptual frameworks ( 38.5 percent) followed by those which incorporated multiple methodologies and literature reviews (23.1 percent, respectively). The remainder of the papers were meta-analytic studies (11.5 percent) and "other" (3.8 percent). The literature review tapped into works which provided a rich diversity of methodologies. Analysis of the journals by discipline shows a diverse spread of the journal titles, with the majority of the papers published in journals collectively termed "Management Reviews" (26.9 percent). The specific journals are: Academy of Management Reviews, Competitiveness Review, International Journal of Management Reviews, and Thunderbird International Business Review. The second largest discipline was collectively termed "Business Studies," which comprised 23.1 percent of the journals from which the papers were reviewed. These journals are: Journal of Business Venturing and Business Process Management Journal.

The findings of the content analysis point to a wide set of definitions and theories used for framing and understanding the knowledge field of strategic alliances, as shown in Tables 3 and 4 . These theories and definitions are understandably organizationally focused and steeped in concepts taken from management and economics. In terms of objectives/goals, the literature is fundamentally focused on the theme of understanding how alliances may be used for competitive positioning within the marketplace. The secondary coding produced seven aspects of "competitive positioning" that corresponded with the rationale for engaging in some type of SA, as shown in Table 2. Under the category of processes and best practices, three major themed areas surfaced from the content analysis with each producing several secondary codes: partner selection (5), organization/community qualities (5), and opportunity structures (4). The primary outcomes/measurement coding was profit maximization. Secondary codes (5) that related to outcomes/measurements were reported as goodwill/reputation, alliance stability, successful joint ventures, innovation, and partner satisfaction. Figure 1 breaks down the objectives, best practices, and measurable outcomes beyond the general coding to provide a more specific view of each area.

In R1, the concepts under the three search parameters objectives, best practices/processes, and outcomes are derived through the reductionist strategy involving primary and secondary codes. Primary codes represent the frequency of the journal articles from which each code is derived from, while secondary codes are a subjective outcome of the decisions made by the two researchers who worked on the coding process. As an example, the concept of 'competitive positioning' under objectives in Table 2 was derived from several primary codes representing the journals and articles reviewed in R1. From these primary codes, certain secondary codes emerged, such as 'competitive strategy', which represents nine primary codes derived from nine articles reviewed. The primary codes for the 'competitive strategy' secondary code are listed in the second column and range from 'competitive edge' to 'gain competitor information' and 'accumulating unique resources for future use'.

Using the same procedure, other primary codes extracted from the remaining articles reviewed in $\mathrm{R} 1$ gave rise to the other secondary codes, such as 'legitimacy/meet requirements', 'growth and financial returns', 'capabilities/developing dynamic capabilities', and 'acquire resources/resource acquisitions' shown in the third column of Table 2. A total of 16 secondary codes emerged from the primary codes associated with the concept of 'competitive positioning'. However, these were further reduced to five: "organizational legitimacy', 'develop dynamic capabilities', 'acquire new resources', 'access new markets', and 'pursue new opportunities'. These were adjudged to be representative of the concept of 'competitive positioning'. Certain secondary codes, such as 'economies of scale', 'efficient use/co-share resources', and 'establish supply chain', were deemed important but not necessary objectives for establishing SAs in R1. The remaining secondary codes were made redundant as they were deemed to be neither important nor necessary. The same iterative process was done for the development of other concepts under processes and outcomes for both R1 and R2. The resultant concepts are summarized in Figure 1. 
Table 3. Key terms and definitions of "strategic alliances" in a general context review.

\begin{tabular}{|c|c|}
\hline Term & Definition \\
\hline Strategic Alliance & $\begin{array}{l}\text { (1) "Relatively enduring interfirm cooperative arrangements, involving } \\
\text { flows and linkages that use resources and/or governance structures from } \\
\text { autonomous organizations, for the joint accomplishment of individual } \\
\text { goals linked to the corporate mission of each sponsoring firm." } \\
\text { (2) "Strategic alliances are voluntary, enduring relationships that involve } \\
\text { resource sharing and joint decision-making." } \\
\text { (3) "Voluntary arrangements [among two or more organizations] } \\
\text { involving the exchange, sharing, or co-development of products, } \\
\text { technologies, or services." } \\
\text { (4) "Strategic Alliances are a variety of purposive inter-organizational } \\
\text { relationships between two or more organizations that share compatible } \\
\text { goals, strive for mutual benefits, and acknowledge a high level of } \\
\text { mutual dependence." } \\
\text { (5) "Strategic Alliances refer to a long-term operative arrangement } \\
\text { between two or more independent organizations that engage in business } \\
\text { activities for mutual economic gain." } \\
\text { (6) "Strategic alliances are voluntary agreements between independent } \\
\text { firms to develop and commercialise new products, technologies, and } \\
\text { services." }\end{array}$ \\
\hline Hybrid Organization & $\begin{array}{l}\text { (Also known as a cooperative relationship) "It is a strategic alliance in } \\
\text { which two or more organizations attempt to compete as a single unit." }\end{array}$ \\
\hline Partnership & $\begin{array}{l}\text { "It is one which is: between organizations, groups, agencies, individuals, } \\
\text { disciplines with common aim or aims, vision, goals, mission or interests, } \\
\text { have joint rights, resources and responsibilities resulting in new } \\
\text { structure(s)." }\end{array}$ \\
\hline International Strategic Alliance & $\begin{array}{l}\text { "Collaborations involving the long-term commitment of resources to } \\
\text { relationships that serve the strategic goals of two or more partners based } \\
\text { in different countries, or whose collaborative operations take place in a } \\
\text { different country to their headquarters." }\end{array}$ \\
\hline
\end{tabular}

(1) "An alliance is a partnership between two or more relatively independent organizations that are united to pursue some ongoing activity or process."

Alliance (2) "Alliances refer to any form of cooperation between firms."

(3) "Alliances, from a strategic perspective, are partnerships between firms where their resources, capabilities, and core competencies are combined to pursue mutual interests."

Acquisitions are transactions in which one firm buys controlling interest in another firm and the acquired business becomes a subsidiary of the acquirer's portfolio.

\begin{tabular}{cl}
\hline \multicolumn{1}{c}{ Strategic Networks } & $\begin{array}{l}\text { "These are composed of interorganizational ties that are enduring and of } \\
\text { strategic significance for the firms entering them." }\end{array}$ \\
\hline $\begin{array}{c}\text { Dyadic Inter-Organizational } \\
\text { Relationships }\end{array}$ & $\begin{array}{l}\text { Dyadic inter-organizational relationships refer to relationships existing } \\
\text { between entrepreneurial ventures and other external organizations. }\end{array}$ \\
\hline Domestic Joint Ventures & $\begin{array}{l}\text { JVs are discrete legal entities created, owned, and influenced by two or } \\
\text { more partner firms that provide resources for, and share in the outcomes } \\
\text { of, the created entity. }\end{array}$ \\
\hline $\begin{array}{l}\text { (1) "Separate legal entity representing partial holdings of two or more } \\
\text { parent firms in which the headquarters of is located outside the location } \\
\text { of one of them. It is subject to the joint control of its parent firms who } \\
\text { are economically and legally independent." } \\
\text { (2) "A type of strategic alliance and refer to business enterprise owned } \\
\text { by two or more companies that share resources and skills. They are legal } \\
\text { entities with one partner firm outside the country where the joint } \\
\text { venture resides." }\end{array}$ \\
\hline
\end{tabular}


Table 4. Key theories used to study the phenomenon in a general context review.

\begin{tabular}{|c|c|c|c|}
\hline Theory & Tenets of the Theory (With Representative Quotes) & Explanation for Alliance Instability & Deficiencies/Gaps \\
\hline $\begin{array}{l}\text { Relational Contracting } \\
\text { (Macneil 1974, 1980) }\end{array}$ & $\begin{array}{l}\text { Relational exchanges, as opposed to discrete exchange, take } \\
\text { place because of a historical and social context, such as trust. } \\
\text { "Relational exchange ... accounts explicitly for the } \\
\text { historical and social context in which transactions take } \\
\text { place and views enforcement of obligations as following } \\
\text { from the mutuality of interest that exists between a set of } \\
\text { parties ..." (Heide 1994, p. 74). }\end{array}$ & $\begin{array}{l}\text { Alliances are essentially relational } \\
\text { contracts, which may run into trouble } \\
\text { if there is a lack of interfirm trust. }\end{array}$ & $\begin{array}{l}\text { A lack of interfirm trust may not explain } \\
\text { most alliance instabilities. Partners with } \\
\text { no historical involvement also succeed. }\end{array}$ \\
\hline $\begin{array}{c}\text { Transaction Cost } \\
\text { (Williamson 1975, 1985) }\end{array}$ & $\begin{array}{l}\text { Assuming economic actors are boundedly rational and } \\
\text { often opportunistic, there is a cost (e.g., of monitoring and } \\
\text { safeguarding) involved in economic transactions. "The } \\
\text { essence of economic activity is the transaction; hierarchies } \\
\text { manage productive activity because transactions costs } \\
\text { make spot market transactions more costly, and therefore } \\
\text { less efficient under certain circumstances" } \\
\text { (Ramanathan et al. 1997, p. 54). }\end{array}$ & $\begin{array}{l}\text { Opportunistic behavior of partner } \\
\text { firms, which is costly and difficult to } \\
\text { control, greatly undermines the } \\
\text { stability of strategic alliances. }\end{array}$ & $\begin{array}{l}\text { The possibility that efficient markets, } \\
\text { with the establishment of firm reputation, } \\
\text { discourage opportunistic behavior } \\
\text { (see Hill 1990). }\end{array}$ \\
\hline $\begin{array}{l}\text { Game Theory } \\
\text { (Axelrod 1984) }\end{array}$ & $\begin{array}{l}\text { This theory studies the choice situations in which the } \\
\text { outcome will depend on what each person involved } \\
\text { chooses to do. "Each partner fears that the other will get the } \\
\text { larger payoff by acting opportunistically while it cooperates } \\
\text { in good faith" (Gulati et al. 1994, p. 61). }\end{array}$ & $\begin{array}{l}\text { Alliances can be viewed as games in } \\
\text { which payoffs from cheating may be } \\
\text { greater than those from cooperating. } \\
\text { Thus, partners may not cooperate } \\
\text { fully. }\end{array}$ & $\begin{array}{l}\text { Recent studies with repeated games } \\
\text { suggest that cooperation could be a likely } \\
\text { outcome. }\end{array}$ \\
\hline $\begin{array}{l}\text { Resource Dependence } \\
\text { (Pfeffer and Salancik 1978) }\end{array}$ & $\begin{array}{l}\text { Because firms depend on resources of other firms, interfirm } \\
\text { relationships constitute a strategic response for controlling } \\
\text { this dependence and uncertainty. "(R)esource dependence } \\
\text { theory views interfirm governance as a strategic response to } \\
\text { conditions of uncertainty and dependence..." (Heide 1994, } \\
\text { p. } 72 \text { ). "The focus is on minimizing interorganizational } \\
\text { dependencies and preserving the organization's autonomy } \\
\text { while recognizing that interorganizational relationships are } \\
\text { necessary to acquire resources" (Gray and Wood 1991, p. 7). }\end{array}$ & $\begin{array}{l}\text { After firms acquire the kind of } \\
\text { resources they need from their } \\
\text { partners, the alliance will be } \\
\text { terminated, thus contributing to a } \\
\text { high degree of instability. }\end{array}$ & $\begin{array}{l}\text { Certain key resources are minimally } \\
\text { mobile and imitable, so that a transfer of } \\
\text { resources may not be possible. }\end{array}$ \\
\hline
\end{tabular}


Table 4. Cont

\begin{tabular}{|c|c|c|c|}
\hline Theory & Tenets of the Theory (With Representative Quotes) & Explanation for Alliance Instability & Deficiencies/Gaps \\
\hline (Social) Network Theory & $\begin{array}{l}\text { A social network can be defined as 'a set of nodes } \\
\text { (e.g., persons, organizations) linked by a set of social } \\
\text { relationships (e.g., friendship, transfer of funds, } \\
\text { overlapping membership) of a specified type' } \\
\text { (Laumann et al. 1978, p. 458). Network perspectives build } \\
\text { on the general notion that economic actions are influenced } \\
\text { by the social context in which they are embedded and that } \\
\text { actions can be influenced by the position of actors in social } \\
\text { networks. }\end{array}$ & $\begin{array}{l}\text { Firms can be interconnected with } \\
\text { other firms through a wide array of } \\
\text { social and economic relationships, } \\
\text { each of which can constitute a social } \\
\text { network. These include supplier } \\
\text { relationships, resource flows, trade } \\
\text { association memberships, } \\
\text { interlocking directorates, } \\
\text { relationships among individual } \\
\text { employees, and prior strategic } \\
\text { alliances. }\end{array}$ & $\begin{array}{l}\text { Social network perspectives were } \\
\text { initially developed for individuals and } \\
\text { their interpersonal networks, but this } \\
\text { needs to be extended to organizations } \\
\text { and their interorganizational networks. } \\
\text { One way to understand the performance } \\
\text { consequences of social networks for } \\
\text { alliances and for the firms entering them } \\
\text { is to think of social networks as } \\
\text { bestowing firms with 'social capital', } \\
\text { which can become an important basis for } \\
\text { competitive advantage (Burt 1997). }\end{array}$ \\
\hline $\begin{array}{l}\text { Agency Theory (Jensen } \\
\text { and Meckling 1976) }\end{array}$ & $\begin{array}{l}\text { Economic activities performed by a group of people have } \\
\text { the advantages of teamwork. However, because agents will } \\
\text { pursue self-serving goals, there is a cost for structuring and } \\
\text { monitoring contracts. "Instead, in agency theory the firm is } \\
\text { viewed as merely a nexus of contracts ... between owners } \\
\text { of the factors of production and customers ... according to } \\
\text { agency theory firms come into existence to exploit the } \\
\text { advantages of teamwork while controlling agency costs ... . } \\
\text { Agency costs include 'the cost of structuring, monitoring, } \\
\text { and bonding a set of contracts among agents with } \\
\text { conflicting self-interests'" (Ramanathan et al. 1997, p. 68) }\end{array}$ & $\begin{array}{l}\text { Managerial decisions regarding } \\
\text { alliances often serve the interests of } \\
\text { managers. To reduce } \\
\text { compensation/employment risk, } \\
\text { managers often proceed to } \\
\text { internalize alliances. }\end{array}$ & $\begin{array}{l}\text { The theory explains managers' motives } \\
\text { for internalizing alliances. However, } \\
\text { when no partner is any more able to do } \\
\text { so than other partners, an equilibrium is } \\
\text { created, and the alliance is sustained. }\end{array}$ \\
\hline $\begin{array}{l}\text { Strategic Behavior (or } \\
\text { Strategic Management) } \\
\quad \text { (Porter 1980, 1985) }\end{array}$ & $\begin{array}{l}\text { This theory is concerned with gaining an advantageous } \\
\text { position against rival firms. Strategies are intended to } \\
\text { achieve various goals, such as capitalizing on opportunities } \\
\text { and minimizing threats. "Strategic behavior posits that } \\
\text { firms transact by the mode which maximizes profits } \\
\text { through improving a firm's competitive position vis-à-vis } \\
\text { rivals" (Kogut 1988, p. 322). } \\
\text { "Strategic management theory ... depicts a focal } \\
\text { organization charting independent courses of action to gain } \\
\text { competitive advantage" (Gray and Wood 1991, p. 9). }\end{array}$ & $\begin{array}{l}\text { Strategic alliances may serve several } \\
\text { goals, including risk reduction, } \\
\text { access to technology and market, and } \\
\text { so on. Unrealistic goal expectations } \\
\text { and goal disparities may lead to } \\
\text { accelerated alliance dissolution. }\end{array}$ & $\begin{array}{l}\text { It seems implausible that alliances are } \\
\text { motivated by unrealistic goal } \\
\text { expectations. }\end{array}$ \\
\hline
\end{tabular}




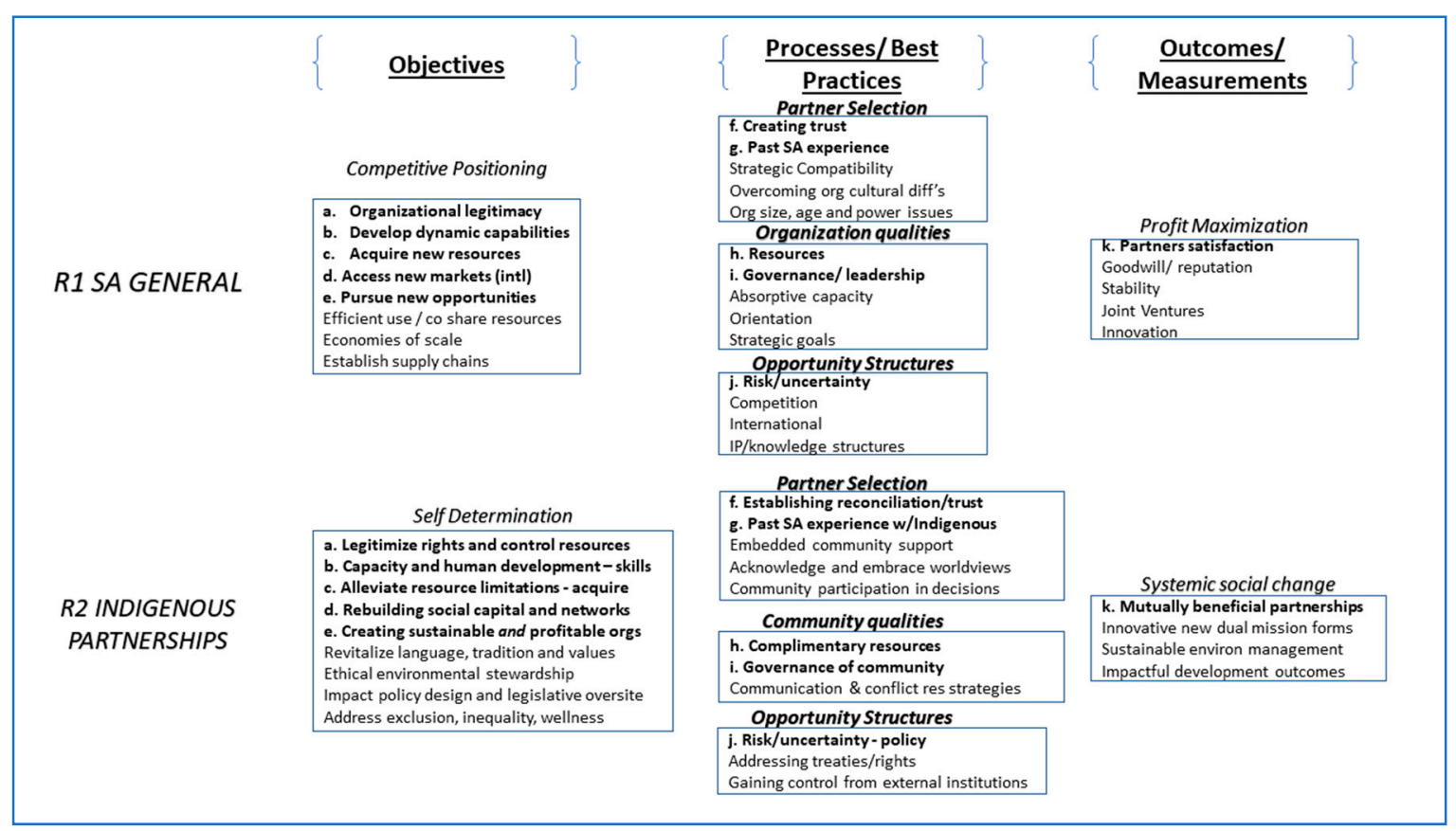

Figure 1. Comparative mapping of R1 and R2 literature.

\subsection{Partnerships in an Indigenous Context Review (R2)}

The history of organizing in an Indigenous context started with socioeconomic development planning and strategies (Anderson and Bone 2003), and then moved to the study of Indigenous entrepreneurship (Hindle and Moroz 2010) with a sub-field that involved a focus on community-based enterprise (Peredo and Chrisman 2006). Greater interest on the phenomenon of SAs as a means for leveraging the resources for starting up new ventures soon followed (Moroz et al. 2014). An underlying focus on partnerships and the significance of natural resources and land-based rights in their development provides a linking foundation across all the divergent focuses and aspects of Indigenous organizing (Dana et al. 2016; Berkes 1999; Anderson and Bone 2003).

Analysis of the literature by discipline shows a diverse spread of the journal titles, with the majority of the papers published in journals collectively termed "Policy and Organizational studies" (21.73 percent). The specific journals are: Organization Studies, Resources Policy, Organizational Dynamics, and Environmental Policy and Law. The second largest discipline is referred to as "Geography and Environmental Studies" (Journal of Environmental Management, Forest Products Journal, Canadian Journal for Forestry Research, and Canadian Journal for Resources), which constitutes 17.39 per cent of the articles reviewed, and "Human Studies" (Journal of Enterprising Communities and Society and Natural Resources), which comprised 13.04 percent of the journals from which papers were reviewed. Papers reviewed also came from the discipline of "Sustainable Development" (13.04 per cent) in such journals as: World Development, Development and Change, and Journal of Sustainable Tourism.

Interesting points of definitional deviation from R1 to R2 were the inclusion of social enterprise alliances, CSR initiatives, specific forms of negotiated and contractual agreements (International Business Alliances (IBAs), co-management agreements, etc.), and multi-stakeholder relationships in the latter. This suggests a much different focus of these studies on sustainability, corporate responsibility, and the developmental aspects of alliances. Joint ventures and mutually beneficial alliances are more typical of the definitions observed in the main SA literature, pointing to obvious overlaps. What was also striking from the review was the lack of transferable theoretical foundations from the two fields, with only "resource-based", "organizational trust", and "culture-based" theories being recognized from the overarching literature. Theories that range from "development" to "sustainability" and "responsibility" are more prominent with attempts to develop new theory on how communities engage 
in entrepreneurship (with alliances and networks being a prominent plank). Tables 5 and 6 provide a concise overview of both definitions and theories encountered.

Table 5. Key terms and definitions of "partnerships" in an Indigenous context.

\begin{tabular}{|c|c|}
\hline Term & Definition \\
\hline Social Enterprises & $\begin{array}{l}\text { A social enterprise is business anchored on social purpose and } \\
\text { whose core objective is organizational sustainability. }\end{array}$ \\
\hline Multi-Stakeholder Partnerships & $\begin{array}{l}\text { Multi-stakeholder partnerships are formalized arrangements } \\
\text { in which organizations from diverse sectors (private, public, } \\
\text { and not-for-profit) commit to work together in mutually } \\
\text { beneficial ways to accomplish goals that they could otherwise } \\
\text { not achieve alone. }\end{array}$ \\
\hline $\begin{array}{c}\text { Impact and Benefit Agreements/Negotiated } \\
\text { Agreements }\end{array}$ & $\begin{array}{l}\text { Negotiated Agreements- "Also known as impact and benefit } \\
\text { agreements are entered into between the aboriginal community } \\
\text { and a corporate entity." } \\
\text { "Negotiated Agreements are binding commercial agreements } \\
\text { between resource companies and native title holders and cover } \\
\text { the following: Land access, Benefit Sharing, and Heritage } \\
\text { Management." }\end{array}$ \\
\hline $\begin{array}{l}\text { Co-Management Arrangements (e.g., } \\
\text { Aboriginal/non-Aboriginal } \\
\text { Relationships/Nation-to-Nation } \\
\text { Relationships) }\end{array}$ & $\begin{array}{l}\text { Co-management type arrangements based on the concept of } \\
\text { co-existence in which Aboriginal and non-Aboriginal cultures } \\
\text { flourish side by side in a mutually-supportive but } \\
\text { non-integrated environment. }\end{array}$ \\
\hline $\begin{array}{l}\text { Partnerships/Joint Ventures/Business } \\
\text { Alliance }\end{array}$ & $\begin{array}{l}\text { Partnerships and joint ventures involve the Inuvialuit } \\
\text { Development Corporation (representing the interests of the } \\
\text { Inuvialuit) and MNCs. They result in the creation of new joint } \\
\text { venture companies in specific sectors. } \\
\text { Joint ventures and business alliances are defined as when First } \\
\text { Nation enters an economic enterprise either independently or } \\
\text { in joint effort with an outside firm. }\end{array}$ \\
\hline $\begin{array}{l}\text { Mutually Beneficial Alliances/Transnational } \\
\text { Corporations }\end{array}$ & $\begin{array}{l}\text { Mutually beneficial alliances refer to strategic alliances } \\
\text { between First Nation and non-First Nation businesses. }\end{array}$ \\
\hline CSR Partnership Initiatives & $\begin{array}{l}\text { CSR partnership initiatives occur when companies cross } \\
\text { organizational and national boundaries to help solve a } \\
\text { problem. }\end{array}$ \\
\hline
\end{tabular}

Considering the three primary categorical areas focused upon: objectives, best practices/processes, and measurable outcomes/performance, the second review also reveals some interesting distinctions and areas of shared importance with the potential for applying learning from the general field (R1) to that of the developing field (R2), as shown in Figure 1. These areas of overlap consist of points (a) to (e) that correspond to objectives, points (f) to (j) under processes and best practices, and point (k) in outcomes and measurements. The remainder of the comparison stands to help illustrate some of the main differences among the two streams of literature. There is also considerable potential for developing theory from context within the field of Indigenous partnerships that may be applied to the general field that may benefit scholars of CRS, as shown in Figure 1 below.

Some of the highlights of this comparison can be found within the primary codes across the three guiding categories. First, the key objectives/goals for corporations who engage in creating partnerships with Indigenous communities include the social, political, and economic priorities of the communities as partners, be that aspirations for community wellbeing, nation rebuilding, self-determination, etc. This stands in stark contrast to the goals of other typical organizational alliance partners, where the main overarching objective is to achieve competitive positioning in the marketplace. 
Table 6. Key theories used to study the phenomenon in Indigenous contexts.

\begin{tabular}{|c|c|c|c|c|}
\hline Name of Theory & Tenets of the Theory & Empirical Studies & $\begin{array}{c}\text { Explanation for Alliance } \\
\text { Performance }\end{array}$ & Deficiencies/Gaps \\
\hline $\begin{array}{l}\text { Resource-based view } \\
\text { (Barney 1991) }\end{array}$ & $\begin{array}{l}\text { "The resource-based view regards } \\
\text { strategy and decision-making } \\
\text { behaviour as embedded within a } \\
\text { wider social structure developed } \\
\text { gradually over time: a process that } \\
\text { provides a } \\
\text { barrier to imitation. SAs represent } \\
\text { social networks and } \\
\text { inter-organisational relationships" } \\
\text { (Moroz et al. 2014, p. 39). }\end{array}$ & $\begin{array}{l}\text { Moroz et al. (2014); } \\
\text { Anderson (1997); Piltan } \\
\text { and Sowlati (2014) }\end{array}$ & $\begin{array}{l}\text { Beyond explaining how firms } \\
\text { gain competitive advantages } \\
\text { through collaborations with } \\
\text { external organizations, the } \\
\text { resource-based view can be } \\
\text { extended to the wider social } \\
\text { structure to understand SAs in } \\
\text { terms of social } \\
\text { networks and } \\
\text { inter-organizational } \\
\text { relationships. }\end{array}$ & $\begin{array}{l}\text { Does not typically encompass natural } \\
\text { rights as resources, nor successfully } \\
\text { translates focus on social capital } \\
\text { creation, extreme resource constraint } \\
\text { considerations, nor the cultural } \\
\text { aspects of tradition, language, and } \\
\text { spirituality as a valued resource. }\end{array}$ \\
\hline $\begin{array}{l}\text { Regulation } \\
\text { Theory/Contingency } \\
\text { Theory/Development } \\
\text { Framework } \\
\text { (Anderson 1997; } \\
\text { Anderson et al. 2006) }\end{array}$ & $\begin{array}{l}\text { Anderson (1997) describes three } \\
\text { central concepts of regulation } \\
\text { theory-regime of accumulation (RA), } \\
\text { modes of social regulation (MSR), } \\
\text { and modes of development (MD). }\end{array}$ & $\begin{array}{l}\text { Moroz et al. (2014); } \\
\text { Anderson (1997); Piltan } \\
\text { and Sowlati (2014); } \\
\text { Anderson et al. (2006) }\end{array}$ & $\begin{array}{l}\text { A people's culture, values, } \\
\text { history, and resources shape } \\
\text { pathways to local development } \\
\text { which integrates into the global } \\
\text { economy while maintaining } \\
\text { unique characteristics of } \\
\text { particular regions } \\
\text { (Anderson et al. 2006). }\end{array}$ & $\begin{array}{l}\text { While explicating how communities } \\
\text { fit into and may influence the market } \\
\text { systems that surround them, it is } \\
\text { generally broad and does not provide } \\
\text { specific insight into the processes for } \\
\text { implementation and the pitfalls or } \\
\text { constraints that act as barriers. }\end{array}$ \\
\hline $\begin{array}{l}\text { Hindle's Bridge } \\
\text { (Hindle and Moroz 2010) }\end{array}$ & $\begin{array}{l}\text { Hindle and Moroz (2010, p. 599) } \\
\text { suggests and implements a } \\
\text { 'diagnostic system for assessing the } \\
\text { influence of community factors' on } \\
\text { the 'conduct and outcome of any } \\
\text { proposed entrepreneurial venture'. }\end{array}$ & Moroz et al. (2014) & $\begin{array}{l}\text { This is inclusive of cultural } \\
\text { boundary spanning, } \\
\text { governance structures, and } \\
\text { institutional development. }\end{array}$ & $\begin{array}{l}\text { "Hindle's bridge removes the } \\
\text { marketplace from the examination of } \\
\text { the community/corporate context. } \\
\text { One cannot examine } \\
\text { entrepreneurship within the context } \\
\text { of SA made between corporations } \\
\text { and communities without } \\
\text { considering the multitude of } \\
\text { marketplace factors that can impinge } \\
\text { or facilitate successful alliance } \\
\text { outcomes" (Moroz et al. 2014, p. 45). }\end{array}$ \\
\hline
\end{tabular}


Table 6. Cont.

\begin{tabular}{|c|c|c|c|c|}
\hline Name of Theory & Tenets of the Theory & Empirical Studies & $\begin{array}{c}\text { Explanation for Alliance } \\
\text { Performance }\end{array}$ & Deficiencies/Gaps \\
\hline $\begin{array}{l}\text { Theory of Organizational } \\
\text { Trust } \\
\text { (McAllister 1995)/Theory } \\
\text { of Aboriginal } \\
\text { Rights/Rights Enquiry } \\
\text { Paradigm }\end{array}$ & $\begin{array}{l}\text { Trust includes both cognitive and } \\
\text { affective dimensions. } \\
\text { Cognitive-based trust develops } \\
\text { through calculated judgements while } \\
\text { affect-based trust is anchored in the } \\
\text { emotions and feelings that people } \\
\text { have for one another. } \\
\text { Trust development in a } \\
\text { multi-stakeholder partnership may be } \\
\text { heightened by the } \\
\text { emotions of the individuals who } \\
\text { come together in it. }\end{array}$ & $\begin{array}{l}\text { Sloan and Oliver (2013) } \\
\text { Everingham and Jannecke } \\
\text { (2006) } \\
\text { O'Faircheallaigh (2008); } \\
\text { Wyatt (2008) }\end{array}$ & $\begin{array}{l}\text { Lack of trust is a key problem in } \\
\text { multi-stakeholder arrangements. } \\
\text { Trust is the "lubricant and glue } \\
\text { of collaborations". Obstacles to } \\
\text { trust development include: } \\
\text { tensions, negative episodes, and } \\
\text { crises lead to failure of } \\
\text { multi-stakeholder partnership } \\
\text { (Sloan and Oliver 2013, p. 1836). }\end{array}$ & $\begin{array}{l}\text { It is limited to the narrow context of } \\
\text { multi-stakeholder partnerships and } \\
\text { may arrive at the same conclusions in } \\
\text { other contexts. }\end{array}$ \\
\hline $\begin{array}{l}\text { Theory of Sustainable } \\
\text { Development/Theory of } \\
\text { Triple Bottom Line/Theory } \\
\text { of Corporate Social } \\
\text { Responsibility }\end{array}$ & $\begin{array}{l}\text { Sustainable development is positive } \\
\text { socioeconomic change that does not } \\
\text { undermine the ecological and social } \\
\text { systems upon which communities } \\
\text { and society are dependent. Its } \\
\text { successful implementation requires } \\
\text { integrated policy, planning, and } \\
\text { social learning processes; its political } \\
\text { viability depends on the full support } \\
\text { of the people it affects through their } \\
\text { governments, their social institutions, } \\
\text { and their private activities. }\end{array}$ & $\begin{array}{l}\text { Lertzman and Vredenburg } \\
\text { (2005); Harris and Khare } \\
\text { (2002); } \\
\text { Barber and Jackson (2012); } \\
\text { London (2012); } \\
\text { O'Faircheallaigh (2008) }\end{array}$ & $\begin{array}{l}\text { Does not provide insight into } \\
\text { the specific mechanisms for } \\
\text { achieving, only the apparent } \\
\text { significance of the objectives. }\end{array}$ & $\begin{array}{l}\text { Does not tap a deep heritage based } \\
\text { and philosophical well of how social } \\
\text { and economic systems must be } \\
\text { integrated with resource (land) } \\
\text { considerations. }\end{array}$ \\
\hline
\end{tabular}


This also stands out under the outcomes/measurements category in that profit maximization is the primary means by which alliances are evaluated as successful within the general literature, whereas systematic social change is the outcome most sought within the context of Indigenous partnerships. Thus, corporations who seek to partner with Indigenous communities and their organizations face completely different goals and measures of success than when seeking to create alliances with other organizations. This of course clearly highlights and distinguishes the risk management approaches to CRS pertaining to firm-centric systems (Kytle and Ruggie 2005) as opposed to Indigenous philosophies on capitalism that involve de-colonization and sustainable involvement in the economy (Corntassel 2012).

When analyzing the primary codings of the two reviews under the processes and best practices category, the contrast is not as pronounced. Although secondary codes deviate somewhat and at times significantly, in actuality, the main processes ascertained through review of both R1 and R2 correspond quite closely to the activities, processes, and best practices surrounding partner selection, the evaluation of organizational (community) qualities when considering strategy, and the opportunity structures that limit or constrain the effectiveness of partnerships and alliances going forward. The next section takes a more detailed look at the comparison of R1 and R2 and how these two fields of research may benefit from cross-pollination.

\section{Analysis and Findings}

The main themes and secondary codes within each primary category of the two frameworks were analyzed, taking cues from Glaser (1965) and Whetten (2009). The resultant analysis was divided into three distinct parts, beginning with areas of theoretical convergence, where the theories, concepts, or perspectives from one body of literature might be harnessed to better inform or guide the work in the other. Building on this, the second part identifies differences in the literature whereby the indicated patterns of theories or perspectives from one set of literature might possibly inform differences in the other set of literature in a specific way. Finally, the third part moves forward by identifying opportunities for developing theories from context and theories of context. This is done by explicitly revealing where the theories of the SA literature may be improved and enriched from the contextual factors contained within the corporate/Indigenous literature (theories from context), while also identifying when established key differences between the two literature bodies may not be easily reconciled or where the failure of theory or concepts might be predicted between them-which then points to the need for developing localized theories of context within the corporate/Indigenous literature body. This concluding section of the analysis is accompanied by a framework generated from the findings that seeks to develop both theory from context and theory of context. The findings of this analysis are discussed in detail within the following subsections.

\subsection{Areas of Theoretical Convergence/Congruence}

Starting with areas of shared significance and convergence between R1 and R2 (the bolded codes in Figure 1), the objectives category identifies and enumerates several areas of between the two strands of literature that requires further exploration. First, achieving legitimacy is one of the possible goals of a strategic alliance or partnership. Legitimacy is often equated to a means for acquiring tangible and intangible resources (Baum and Oliver 1991; Suddaby and Greenwood 2005). In the case of R1, this is represented by (a) or 'organizational legitimacy' while in $\mathrm{R} 2$, it is represented by (a) or 'legitimize rights or control resources'. In partnerships, the legitimacy process is alloyed to defining and defending the inalienable rights to control the lands and resources once controlled (although never ceded in treaty agreements).

Second, the two strands of literature share aspects of the concept of capacity development being represented by (b) both in R1 and R2 as "develop dynamic capabilities" and "capacity and human development", respectively. The only differences in this point are the organizational and community contexts; with the latter being highly constrained and often viewed from the perspective of underdevelopment. 
Third, both strands of literature signal the importance of resources represented by (c), where the development of theories, concepts, and perspectives on how alliances in R1 'acquire resources' may be useful to plotting out how Indigenous communities may not only acquire new resources, but 'alleviate resource limitations' placed upon what resources they do have in their control.

Fourth, both R1 and R2 acknowledge the role of 'social networks and capital' and 'new markets' represented by (d) in the two streams of literature, respectively. The role of social networks and capital within the alliance literature is highly relevant to how Indigenous communities must look to new markets for opportunities and how partnerships may help gain access to new markets.

Finally, drawing from the above, the two streams of literature show that the profitability is a key issue and is represented by (e) in R2 as the objective of creating 'sustainable and profitable organizations' and 'pursue new opportunities' in R1. While Indigenous organizations may have dual missions, the issue of profitability may add a layer of complexity to the opportunities they pursue through partnerships.

Under the category of processes and best practices, not only is their convergence at the primary theme level, there are also several areas of shared interest between R1 and R2. Considering process of partner selection, there is a great deal of significance to both streams of literature in the concept of trust represented by (f) in R1 as 'creating trust' and 'establishing reconciliation/trust' in R2. As Indigenous communities around the world continue to use corporate partnerships to establish reconciliation between polities and cultures, the aspect of trust in this regard is deeply layered and may be well served by the vast amount of work on the intricacies of alliance trust. Furthermore, past experience with the process of alliance formation is also found to be key in both fields, represented by (g) as 'past $S A$ experience' in R1 and 'past SA experience with Indigenous' in R2. The aspects of combined experience and trust support the need for the recognition of the time, energy, and nuanced learning practices involved with forming partnerships from the perspective of R2. It is thus surmised that work from a purely organizational perspective may be beneficially extended when considering best practices in partner selection to Indigenous contexts.

Under the theme of organizational/community qualities, point (h) represented by 'resources' in $\mathrm{R} 1$ and 'complimentary resources' in R2, at first look like clear areas of overlap. However, how $\mathrm{R} 1$ and R2 conceptualize resources differs considerably in some areas. For R2, the emphasis is clearly on seeking tangible resources that are complimentary to their own intangible resources that flow from social contracts such as treaty obligations, government fiduciary responsibilities, and the complexities enveloped in the translation of rights between highly divergent worldviews. This is unlike R1, where resources are more tangible to property rights regimes that intersect resources such as knowledge, capacity, and market access-which may be better and more easily defined. Nevertheless, alliances involve the process of evaluation of the qualities of potential partners and thus, striving for complementariness, is often a key objective.

Furthermore, aspects of governance (i) diverge between the two streams of literature in that R1 considers management, organizational structure, and board governance, while R2 also adds to these factors the importance of political elements that are more attuned to the community level of political leadership. Nevertheless, emphasis on good governance and leadership in all its forms allows for the potential transfer and application of theories in management and alliances into the domain of Indigenous partnerships (see Cornell and Kalt 2000, as an example).

Turning to the last set of secondary codes derived from the theme of opportunity structures, both R1 and R2 emphatically evince the significance of risk and uncertainty in the alliance process. Much of the work concluded in the R1 stream may have merit when seeking to inform the aspects of the institutional and policy-based structures that currently stand as, at the least, elaborate constraints and at worst, additional layers of risk and uncertainty with respect to Indigenous partnerships. As the ground continues to shift on how legislative and market actors around the world attempt to deal with the fiduciary responsibilities that clog developmental initiatives and objectives, the body of knowledge developed on alliance uncertainty and risk may provide a great deal of insight into approaches for 
understanding and studying partnerships involving Indigenous and non-Indigenous organizations and the opportunity structures they face (Gordon et al. 2017).

Last of all, while primary themes of profit maximization and systemic social change stand out as wide chasms between the two streams of literature, the category of outcomes/measurements still share at least one area of overlap in point $k$, that of partner satisfaction and achieving mutually beneficial partnerships. Once again, it is the differences in the interpretation of these thematic codes that are of interest when considering the means and not the ends of how partnerships are measured and evaluated as successful. In most cases of partnership success in R1, it is due to the transactional nature of each partner working toward a stable and profitable arrangement. This transactional function is once again stretched beyond economic and financial measurements in R2 through the need for 'relationship development' that otherwise would impede stable and consistent movement toward Indigenous goals, while still satisfying the essential problems of survival in that partners must still formulate success as financial to a certain extent.

\subsection{Identification of Differences in the Literature}

There are also areas in the R1 and R2 frameworks that present little direct congruence. Secondary coded themes may therefore be viewed as key distinctions between, or gaps where more research needs to be contextually developed and applied to better serve alliances formation and success, either between Indigenous and non-Indigenous entities or as a means by which themes and perspectives generated may be migrated back to the general literature.

Considering the guiding category of objectives, the theme of self-determination suggests that (individual and group) motivations for engaging in organizing and development are linked to wellbeing, autonomy, and the resolution of conflict much more in R2 than in R1 (Ryan and Deci 2000). The concept of wellbeing framed here is more contextually distinct but follows similar foundational perspectives that may be attuned to social and economic wellbeing. The drive for autonomy and self-government is revealed to be a key tenet of Indigenous peoples' objectives for entering SAs. This is due in part to the successive and varied colonial policies across the world (see Sawyer and Gomez 2012) that has resulted in the outright severing of social, cultural, and political autonomy, to the creation of conditions that yield exclusion, social disadvantage, and inequality for Indigenous peoples, communities, and nations. Thus, the pursuit and participation of alliances, while contradictory in terms to the goal of autonomy, is often a direct means for impacting policies for gaining control of and legitimizing natural and land-based rights to self-governance while indirectly revitalizing heritage and protecting local and global environmental systems; all while attempting to also address socioeconomic needs through the generation of wealth.

SAs are thus viewed as a way for Indigenous communities to replenish human, social, and cultural capital within communities through interface with the market on their own terms, notwithstanding government policies and related societal barriers. Thus, alliances with corporations may sometimes be used as a point of instigation for drawing attention to institutional voids that exist because of a lack of Indigenous autonomy within the greater polity. These themes may be combined with the focus on SAs as a means for informing how corporations may engage local communities in their own objectives, such as co-sharing resources, creating economies of scale, and establishing supply chains, among others, by providing an agenda for opening dialogue among local stakeholders and communities.

Under the guiding category of processes and best practices, there are also distinctions identified between the two streams of literature that serve to indicate where contextual factors appear to be distinct. While partner selection is a shared general theme, the fact that organizational partnerships must be open to direct community participation, acknowledge and embrace divergent worldviews, and provide community support that is embedded (direct relationship building), reveals a direct gap between R1 and R2.

Furthermore, within the processes/best practices general themes, the specific contextual themes suggest there are two related areas that are distinct and significant gaps to these types of partnerships. 
First, the one continuous theme that emerges from R2 is the need to understand Indigenous rights with respect to lands, resources, and belief systems. First, these rights are recognized and operate at the supranational level (e.g., The United Nations Declaration on the Right of Indigenous Peoples and the regulations of the World Bank and affiliates regarding financing of projects on Indigenous lands), the national or state level (i.e., treaties and court decisions), and sub-national level, where local conditions may vary considerably even with an overarching state-wide system (Anderson 2015). Second, there are national and sub-national legal/regulatory/policy regimes that impact Indigenous/corporate relationships both directly and indirectly. These include such things of general application in areas such as environmental protection, pipelines, forestry, non-renewable extractive industries, and the like. These regulatory regimes often contain special provisions with respect to Indigenous rights as discussed above. An example in Canada can be found in the Supreme Court decisions around the 'duty to consult' and subsequent government policy and regulatory changes to these laws and regulations of general application to foster compliance with the 'duty to consult' and other similar decisions.

This regulatory environment must also be well understood as it presents both barriers to and opportunities for strategic alliance success. The need to separate policies into a state and local level is significant since differences exist between how nation-state policies are operationalized, given that local governance policies may vary based on a wide range of factors that include adaption of special legislative tools, the level of autonomy of policy making from the state, and how local community policies may overlap or conflict. Thus, one of the main concerns for Indigenous communities in establishing partnerships is to engage in processes where they may gain as much control as possible, as the opportunity structures they face are often limiting with respects to their ability to control their own resources.

Last of all, under measures and outcomes, the key differences between the two strands of literature may be described as the types of organizational forms that are created and how success is measured. The themes emerging from R2 are squarely indicative of the importance of sustainable outcomes as a key measurement of success. Linked to sustainability is whether partnerships can contribute to the socioeconomic wellbeing of Indigenous communities and organizations. These two factors are interlinked with the formation of innovative new hybrid structures for generating wealth while contributing to the former measures. In contrast, R1 reflects outcomes that are derived from theories of the firm that stress success measured as profitable, stable, and innovative joint ventures that exemplifies the general literature and its focus on wealth maximization. As part of this focus, reputation and goodwill stand as proxies for generating further resources upon legitimacy that also contribute to the overall outcome of wealth maximization. Drawing upon the latter, a clear area of bridging between the two streams of literature stands to be made up by examining the highly complex concept of legitimacy, and how it may relate to CRS.

\subsection{Developing Theory from Context and Theory of Context}

An approach, grounded in Indigenous knowledge systems and worldviews, was generated from these findings that seek to develop both theory from context and theory of context that serves to directly set out the key factors that the partnership process must identify and successfully navigate to generate the key outcome of CRS legitimacy in both general and specific contexts, as shown in Figure 2. This approach was developed from several iterations of bridging and surfacing of the mapped codes that were not directly overlapped (themes in Figure 1). Returning to the original problem and question as to how actors in SAs may mobilize strategies for enacting legitimate CRS programs, we find that there are four key factors that may be generalized to from the formation of Indigenous partnerships: (1) relevance of local modes of regulation; (2) relevance of distinctness in Indigenous knowledge systems and worldviews; (3) relevance of social bonding; and (4) relevance of specific group opportunity constraints. Each of these four main factors is broken down from the examination of partnerships in an Indigenous context to provide a theoretical framework 'of context' that helps to explain the key aspects of each concept. 


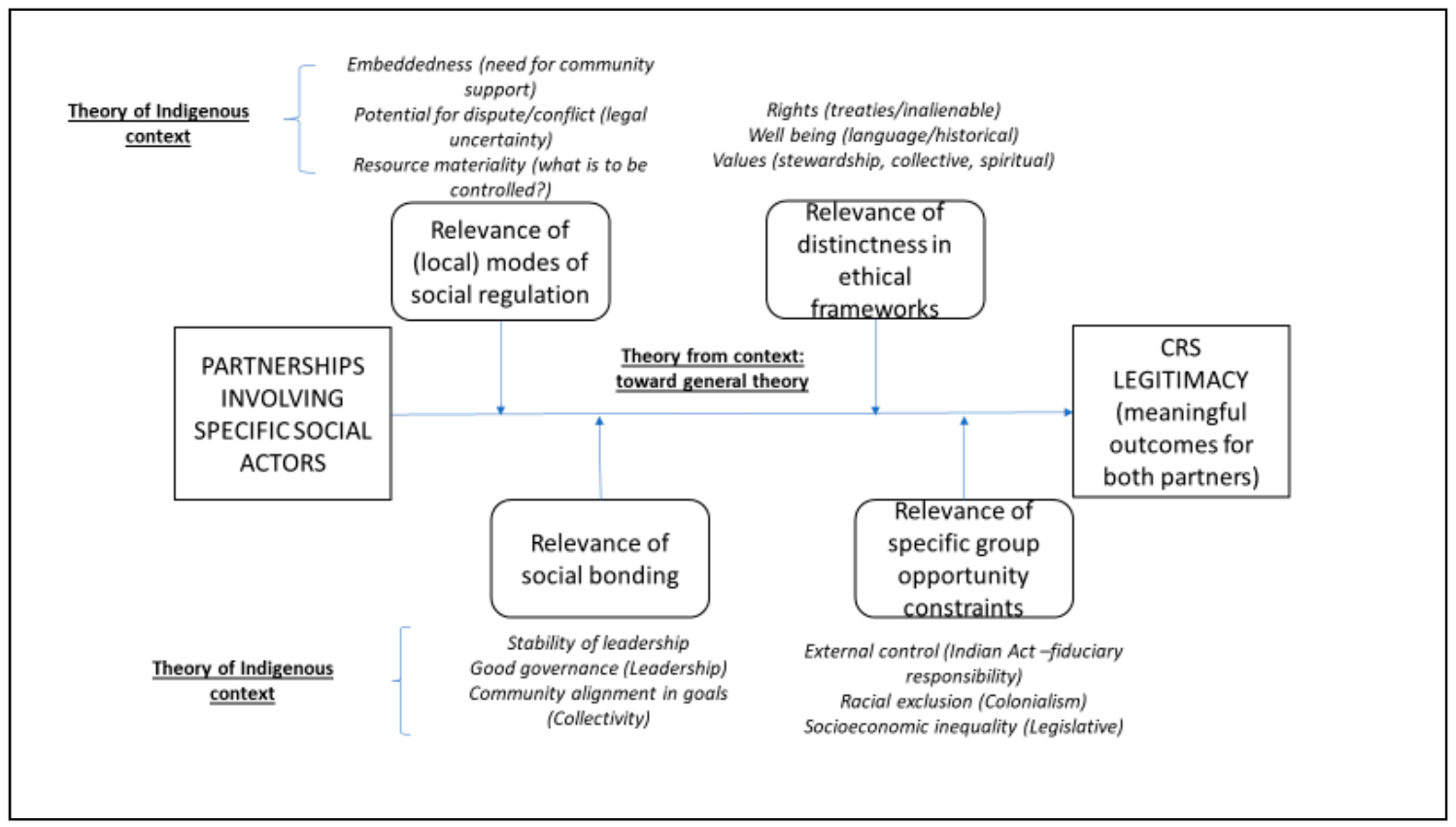

Figure 2. Key concepts relevant to achieving corporate responsibility and sustainability (CRS) legitimacy through strategic alliances.

First, both partners must understand the aspects of social regulation and the level of control that partners have within a particular mode of regulation (be it geographically, local, market based, or technology spaced) that may be used to leverage the other in the course of negotiations and implementation. From an Indigenous perspective, there may be a high to low level of embeddedness required by the partner, dependent upon the type and level of support required. Furthermore, if local modes of social regulation are mired by legal uncertainty, dispute and conflict resolution processes are necessary, especially when there are resources to be controlled by either partner. Second, the concept of social bonding must be taken into account when dealing with specific social actors as they may be disparate, having different types of governance and leadership. In the case of Indigenous contexts, the stability of leadership, the capacity of leadership, and the level of collectivity (decision making and ratification) must be considered by partners when designing strategies for successful Indigenous/corporate partnerships.

Third, as indicated above, partnerships must be aware of distinct or divergent Indigenous knowledge systems and worldviews that exist amongst partners and take steps to understand, translate/take on, and operate under agreed upon frameworks. With respect to the context of Indigenous people, the need for transmuting philosophical worldviews about rights, how wellbeing is valued and measured, and the collective values of ecological and spiritual essence must be successfully merged with CRS values from a market position (sponsorship, community investment, license to operate, etc.). Fourth, it also appears critical to assess the relevant constraints of each partner, especially if one of the partners involves a social actor that may not have the same types of opportunity structures as a corporate partner. This is plainly evident in an Indigenous context, through the fiduciary responsibilities, and thus the limitations imposed by the Indian Act, and the elements of racial exclusionism enforced by the dominant polity and the conditions of socioeconomic inequality that have been legislatively induced over time.

Following Whetten (2009), the framework therefore sets out specific (theories of context) and general (theories from context) concepts and conditions via the alloyed framework that are necessary to be explored and satisfied to better position partners for achieving CRS legitimacy through SAs. 


\section{Discussion, Conclusions, and Future Research}

In line with the call in the academy for conceptual studies which theorize the interplay between systemic constraints, organizational responses, and individual action, this research makes valuable contributions that deepen understanding on how actors make sense of systemic constraints and how this affects their strategies, day-to-day behavior, interactions, and relationships (De Bakker et al. 2005).

This review clearly suggests that future research within the field of Indigenous partnerships (R2) will be well-served by embracing theory, concepts, and processes developed within the overarching field of SAs (R1). Thus, the foundational perspectives of agency theory, transaction cost theory, and Resource-based View (RBV), as well as more concentrated conceptual areas, such as organizational learning, absorptive capacity, theories of trust, and new vistas in exploring the interface of cultural and organizational logics, principally the collective paradigm, are appropriate foundations for researchers who study Indigenous/non-Indigenous alliance formation.

However, while the general themes contributing to successful SAs are the same between R1 and R2, making the study of best practices and processes relevant, it is important to emphasize that context matters in all SAs. Therefore, while building on existing work on SAs, there is a clear need to modify these theories and practices to improve context sensitivity considering the many distinct themes and factors such as those that have emerged from the R2 review (Whetten 2009). There is also a danger of applying general theories from R1 to R2 without knowing the potential limitations and boundaries of their explanatory power, especially when the characteristics and key factors being observed differ in substantial ways (Rousseau and Fried 2001). Thus, not only must researchers begin to test and mark the efficacy of general theories but also must determine when contextual factors demand the development of context-specific explanations for the causal patterns identified and the distinct mediating circumstances involved.

Furthermore, the key overarching thematic differences between the mainstream context (R1) and the emerging field (R2) is the former's goal for using alliances to attain competitive positioning with profit maximization as its main measurable outcome, while the objective of the latter (that is Indigenous communities) is to use partnerships to move toward self-determination aimed at meaningful and sustained systematic socioeconomic change. This result clearly mirrors current conversations in Indigenous entrepreneurship on how business and society functions and the need for corporations to take on Indigenous knowledge systems and worldviews to navigate these divergent positions of civil society stakeholders as well as consumers (Marens 2016; Liket and Maas 2016). It also points to areas of conflict and opportunity when considering the value of engaging with divergent and/or local perspectives of value that may be significant to how corporations lay out strategies appropriate for achieving legitimacy through their CRS activities (Fyke et al. 2016). In this sense, R2 is more in tune with the collective approach and has implications for R1 in that corporations can learn and be more collective in approach as they build SAs generally.

There are also implications for how the emerging research in Indigenous alliances may be applied to better inform the general literature focused on SAs (R1), especially when considering their role in achieving legitimate CRS strategies. On one hand, Indigenous communities want to partner with corporations in socioeconomic development SAs. They wish to build on their rights and gain control over their resources to improve their socioeconomic circumstances while revitalizing their languages, respecting their traditions, and values, and protecting the environment. This is also synonymous with the goal of the collective paradigm which situates human flourishing at the core. Thus, understanding the Indigenous knowledge systems and worldviews that guide Indigenous stakeholders as a distinct group in their desire to achieve these goals is tantamount to the success of any CRS strategy employed by partners.

On the other hand, corporations have incentives to enter such alliances to secure access to land and resources subject to Indigenous rights, as well as to bolster a general social license to operate. Additionally, corporations are becoming increasingly faced with demands from all sides to show corporate responsibility and sustainability concerns for the environment. These respective aspirations 
create the potential for the formation of mutually beneficial SAs that may provide legitimacy to both corporate and Indigenous partners. The processes essential for creating and stabilizing such alliances must, at a minimum, include the consideration of (at least) four factors identified as: (a) the relevance of new or divergent Indigenous knowledge systems and worldviews acknowledging a radically different set of worldviews that diverge from most neoliberal thinking on how society and business operates; (b) the relevance of social bonding and understanding community governance systems that include how communities, leaders, and organizations function within the decision-making processes with regard to alliance formation and operation; (c) the relevance of the local modes of social regulation that exist and how they may impact the partnership process from aspects of control and power, especially in cases of materiality, and especially when one partner benefits at the cost of another (Powell et al. 2017); and (d) understanding the relevance of social actor or group constraints that emerge from the confluence of local, national, and supranational policies, laws, regulations, and the like, all of which may impact the alliance formation activities in many significant ways.

Our analysis of the two streams of literature finds that corporations which have met with success in mainstream contexts may need to pay attention to the holistic worldviews of Indigenous communities, as well as be able to determine when these Indigenous knowledge systems and worldviews are not fully embraced, as the bonding aspects of communities that allow for them to successfully mobilize initiatives and organizations may not always be properly functioning. This is an exciting area of research considering that the worldviews of Indigenous communities mirror much of what is being reinvigorated within the management literature in the discussions pertaining to the relationship between business and society, especially regarding corporate social responsibility, partnership development (Tavanti et al. 2017; Richards et al. 2016), and Indigenous Entrepreneurship (Curry et al. 2016; Ali 2016; Bindlish et al. 2017; Lawrence and Larsen 2017).

In many ways, these worldviews may be highly insightful Indigenous knowledge systems and worldviews to draw from when charting new ways of viewing important objectives within the mainstream literature (such as the creation of social hybrid ventures). This is especially so when considering how to alleviate resource limitations, impact policy designs, protect the environment, and pursue human flourishing underpinned by protection of their wellbeing and dignity (Pirson 2017). Charting the processes of 'meaningful participation' of Indigenous communities and knowledge to create ambicultural governance systems within alliance structures appears to be a fruitful area of research for both communities and corporations (Ruwhiu and Carter 2016).

Researchers and practitioners must also provide insights into how to encourage and enlist community participation in the decision-making process as part of the partner selection process. Indigenous knowledge systems and worldviews may essentially speak to the need for compatibility and overcoming both moral and philosophical differences about the way the world should work, which is germane to alliance success in the mainstream context. This is not an easy process to navigate considering the governance styles of corporations and communities that often breed conflict (Fontana et al. 2017). Moreover, while power imbalances and aspects of control in the mainstream literature suggest that the attributes of organizational size, age, and economic strength may impact upon the processes undertaken, these same strengths may end up as liabilities when applied to an Indigenous context and not fully transferrable to the emerging field (for example, see Gallagher 2012 for a long list of legal outcomes where the small and disadvantaged communities have toppled the large and munificent corporates).

Last of all, the conditions and measurements of alliance success within the R2 framework are found to be aligned with social transformational aspects of systemic change, both economic and social/environmental, and are thus difficult to measure. This is not surprising as the two most prolific paradigms of CRS have continental European and Anglo-American roots (Obalola et al. 2016). One promising area of research is in the field of social license to operate (Moffat et al. 2016). Current social measurements, such as health, education, justice, and social indicators (Griffiths et al. 2016), as well as economic measures of job creation and community wealth/businesses operations, may not truly capture the essence of the socioeconomic change that is required to accurately portray and measure 
success from an Indigenous perspective. Measures of rights and wellbeing derived from the traditional recognition of factors that often have little importance in market or governmental reporting would thus be a necessary starting point. There is a burgeoning body of literature steeped in the collective paradigm (Whetten 2009; Pirson 2017 which seeks to develop a twenty-first century management theory of responsible business and emphasizes 'the protection of human dignity and the promotion of wellbeing'.

Furthermore, these measures may benefit from considering the sensitive contextual aspects of specific actors or communities. For example, in an Indigenous context, the split between urban and reserve (local) with regard to the make-up of these communities serves to highlight some of the bonding issues that exist when collective decision-making and dissemination of material resources are engaged. How bonding and bridging capacities may be evaluated and/or the re-establishment, re-invigoration, or reshaping of measures of dependency, heritage retention, and language may add or subtract value from these communities is also a warranted area of research on social bonding aspects in partnership development (Tavanti et al. 2017; Richards et al. 2016). This stream of study also warrants more place-based emphasis on how corporations may engage communities to develop socioeconomic alternatives for successful alliance formation (Ehrnström-Fuentes and Kröger 2017). These are all important areas where the leveraging of partnerships between Indigenous and non-indigenous entities may help to gain specific insights into how to better align to the goals of corporate and social actors when seeking to build CRS strategies around SAs.

\section{Limitations}

The literature review conducted within the scope of this paper highlights the similarities and differences between the two literature streams on SAs in general and corporate/Indigenous partnerships in particular. This process subsequently identifies several avenues for future research overlooked in the divergence of the two streams of literature. However, it should be noted that while a systematic literature search was performed, the literature review itself involved a targeted sample of the search results as opposed to a systematic review of all the papers identified. While this course brings with it the possibility of overlooking publications with vital implications relevant to the objectives of this study, the calculated inclusion of systematic literature reviews and meta-analytic publications within the scope of the targeted sample prepared for review ought to minimize the possibility of this potential omission. It should also be noted that the selection criteria for the literature search was focused primarily on works published between the years of 2005 and 2015 . While the inclusion of seminal and eclectic papers beyond this date range maximize the magnitude of the targeted literature sample, it is nonetheless possible that less well-known studies outside of this date range may have been omitted in the search.

The selection of concepts through thematic analysis (coding) is based on convenience in line with the qualitative methodological considerations. This limits the generalizability of conclusions when compared to those obtained through meta-analysis, which has greater statistical power through its considerations for same-source variance and construct validity.

\section{Conclusions}

This preliminary work seeks to stretch the boundaries by reconsidering the links between capitalism, corporations, and society from an Indigenous entrepreneurship perspective in the quest to advance humanity within planetary boundaries (Whiteman et al. 2013). The initiation of cross-disciplinary and contextualized research is burgeoning and offers different ways of looking at both old and new problems. What is exciting about the confluence of research in the field of SAs in the contextualized space of Indigenous communities is that there is much for management scholars to learn from different epistemological and axiological perspectives where belief structures differ and values are often not well aligned. Yet the promise of incorporating the beliefs and values of those cultures that walk the tightrope of individualistic systems, while attempting to balance many of 
the opposing values inherent within it, is flush with opportunities for revisiting Indigenous values as foundational perspectives for emerging trends in CSR, and the Indigenous knowledge systems and worldviews upon which they rest. This paper is (part of) a first step in setting out arguments for how Indigenous knowledge systems (R2) may have much hidden and non-obvious value for corporate partners (theory of the firm) seeking competitive advantages and CRS legitimacy (R1). The comparison of this literature has illuminated the need for Indigenous knowledge systems and worldviews in organizations (and beyond, society) through the building of cross cultural relationships for achieving multiple objectives, ranging from development that provides wealth and supports the self-determinative efforts of Indigenous people to the overarching goal of the collective paradigm, which is to enhance their dignity and wellbeing (R2).

Author Contributions: Conceptualization, P.W.M.; Funding acquisition, P.W.M.; Investigation, A.I.J.; Methodology, A.I.J., P.W.M. and R.B.A.; Project administration, P.W.M.; Writing—original draft, A.I.J., P.W.M., M.G. and R.B.A.; Writing-review \& editing, A.I.J., P.W.M., M.G. and R.B.A. All authors have read and agreed to the published version of the manuscript.

Funding: Funded in part by a grant from the Social Sciences and Humanities Research Council of Canada.

Conflicts of Interest: The authors declare no conflict of interest.

\section{References}

Ackers, Barry. 2015. Ethical considerations of corporate social responsibility-A South African perspective. South African Journal of Business Management 46: 11-21. [CrossRef]

Albers, Sascha, Franz Wohlgezogen, and Edward J. Zajac. 2016. Strategic alliance structures: An organization design perspective. Journal of Management 42: 582-614. [CrossRef]

Ali, Saleem H. 2016. The ethics of space and time in mining projects: Matching technical tools with social performance. Journal of Business Ethics 135: 645-51. [CrossRef]

Anderson, Robert Brent. 1997. Corporate/Indigenous partnerships in economic development: The First Nations in Canada. World Development 25: 1483-503. [CrossRef]

Anderson, Robert Brent. 2015. Tracking the Statutory Tenure Rights of Indigenous Peoples and Local Communities in Canada. Washington: Resources Rights Initiative.

Anderson, Robert Brent, and Robert M. Bone, eds. 2003. Natural Resources and Aboriginal People in Canada: Readings, Cases, and Commentary. Concord: Captus Press.

Anderson, Robert Brent, Leo Paul Dana, and Teresa E. Dana. 2006. Indigenous land rights, entrepreneurship, and economic development in Canada: “Opting-in" to the global economy. Journal of World Business 41: 45-55. [CrossRef]

Axelrod, Robert. 1984. The Evolution of Cooperation. New York: Basic Books.

Banerjee, Subhabrata Bobby. 2008. Corporate social responsibility: The good, the bad and the ugly. Critical Sociology 34: 51-79. [CrossRef]

Bansal, Pratima, and Kevin Corley. 2011. The coming of age of qualitative research: Embracing the diversity of qualitative methods. Academy of Management Journal 54: 233-37.

Barber, Marcus, and Sue Jackson. 2012. Indigenous engagement in Australian mine water management: The alignment of corporate strategies with national water reform objectives. Resources Policy 37: 48-58. [CrossRef]

Barker, Adam. 2010. From adversaries to allies: Forging respectful alliances between Indigenous and settler peoples. In Alliances: Re/envisioning Indigenous-non-Indigenous Relationships. Edited by Lynne Davis. Toronto: University of Toronto Press, pp. 316-33.

Barney, Jay. 1991. Firm resources and sustained competitive advantage. Journal of Management 17: 99-120. [CrossRef]

Barton, Dominic. 2011. Capitalism for the long term. Harvard Business Review 89: 84-91.

Baum, Joel A. C., and Christine Oliver. 1991. Institutional linkages and organizational mortality. Administrative Science Quarterly 36: 187-218. [CrossRef]

Belal, Ataur Rahman, Stuart M. Cooper, and Robin W. Roberts. 2013. Vulnerable and exploitable: The need for organisational accountability and transparency in emerging and less developed economies. Accounting Forum 37: 81-91. [CrossRef] 
Berkes, Fikret. 1999. Sacred Ecology: Traditional Ecological Knowledge and Resource Management. Philadelphia: Taylor \& Francis.

Berkes, Fikret, and Helen Ross. 2013. Community resilience: Toward an integrated approach. Society E Natural Resources 26: 5-20.

Bindlish, Puneet, Ankur Joshi, Priyanka Dutt, Pawan Verma, and Shaveta Arora. 2017. Researcher preparation for Indigenous fundamental research through collaborative participation. In Implementing Communities of Practice in Higher Education. Edited by Jacquie McDonald and Aileen Cater-Steel. Singapore: Springer, pp. 107-29.

Brooks, Simon. 2005. Corporate social responsibility and strategic management: The prospects for converging discourses. Strategic Change 14: 401-11. [CrossRef]

Burt, Ronald S. 1997. A note on social capital and network content. Social Networks 19: 355-73. [CrossRef]

Campbell, John L. 2007. Why would corporations behave in socially responsible ways? An institutional theory of corporate social responsibility. Academy of Management Review 32: 946-67. [CrossRef]

Coates, Kenneth, and Brian Lee Crowley. 2013. New Beginnings: How Canada's Natural Resource Wealth Could Re-Shape Relations with Aboriginal People. Retrieved from the Macdonald-Laurier Institute. Available online: https://www.macdonaldlaurier.ca/files/pdf/2013.01.05-MLI-New_Beginnings_Coates_vWEB.pdf (accessed on 17 January 2016).

Corbridge, Stuart. 1989. Marxism, post-Marxism, and the geography of development. In New Models in Geography. Edited by Richard Peet and Nigel Thrift. London: Unwin Hyman, vol. 1, pp. 224-54.

Cordoba, Diana, Marta Chiappe, Jesse Abrams, and Teresa Selfa. 2017. Fuelling social inclusion? Neo-Extractivism, state-society relations and biofuel policies in Latin America's southern cone. Development and Change 49: 63-88. [CrossRef]

Cornell, Stephen, and Joseph P. Kalt. 2000. Where's the glue? Institutional and cultural foundations of American Indian economic development. The Journal of Socio-Economics 29: 443-70. [CrossRef]

Corntassel, Jeff. 2012. Re-envisioning resurgence: Indigenous pathways to decolonization and sustainable self-determination. Decolonization: Indigeneity, Education \& Society 1: 86-101.

Curry, John A., Han Donker, and Paul Michel. 2016. Social entrepreneurship and Indigenous people. Journal of Co-Operative Organization and Management 4: 108-15. [CrossRef]

Dana, Leo Paul, Bob Kayseas, Peter William Moroz, and Robert Brent Anderson. 2016. Toward an understanding of Aboriginal/Indigenous rights and their impact on development. Presented at the Annual Meeting of the Academy of Management, Briarcliff Manor, NY, USA, November 30. [CrossRef]

Das, Tushar K., and Bing-Sheng Teng. 2000. A resource-based theory of strategic alliances. Journal of Management 26: 31-61. [CrossRef]

De Bakker, Frank G. A., Peter Groenewegen, and Frank Den Hond. 2005. A bibliometric analysis of 30 years of research and theory on corporate social responsibility and corporate social performance. Business $\mathcal{E}$ Society 44: 283-317.

de los Reyes, Gastón, Jr., Markus Scholz, and N. Craig Smith. 2017. Beyond the “Win-Win": Creating shared value requires ethical frameworks. California Management Review 59: 142-67. [CrossRef]

Denzin, Norman K., and Yvonna S. Lincoln. 2011. The SAGE Handbook of Qualitative Research. Los Angeles: Sage.

Ehrnström-Fuentes, Maria, and Markus Kröger. 2017. In the shadows of social licence to operate: Untold investment grievances in Latin America. Journal of Cleaner Production 141: 346-58. [CrossRef]

Everingham, Mark, and Crystal Jannecke. 2006. Land restitution and democratic citizenship in South Africa. Journal of Southern African Studies 32: 545-62. [CrossRef]

Fontana, Alejandro, Susana Sastre-Merino, and Maritza Baca. 2017. The territorial dimension: The component of business strategy that prevents the generation of social conflicts. Journal of Business Ethics 141: 367-80. [CrossRef]

Fyke, Jeremy P., Sarah Bonewits Feldner, and Steven K. May. 2016. Discourses about righting the business $\leftarrow \rightarrow$ society relationship. Business and Society Review 121: 217-45. [CrossRef]

Galbreath, Jeremy, and Paul Shum. 2012. Do customer satisfaction and reputation mediate the CSR-FP link? Evidence from Australia. Australian Journal of Management 37: 211-29. [CrossRef]

Gallagher, Bill. 2012. Resource Rulers: Fortune and Folly on Canada's Road to Resources. Brighton: Bill Gallagher.

Glaser, Barney G. 1965. The constant comparative method of qualitative analysis. Social Problems 12: 436-45. [CrossRef] 
Gordon, Moses E. G., Bob Kayseas, and Peter W. Moroz. 2017. New venture creation and opportunity structure constraints: Indigenous-controlled development through joint ventures in the Canadian potash industry. Small Enterprise Research 24: 1-22. [CrossRef]

Gray, Barbara, and Donna J. Wood. 1991. Collaborative alliances: Moving from practice to theory. The Journal of Applied Behavioral Science 27: 3-22. [CrossRef]

Griffiths, Kalinda, Clare Coleman, Vanessa Lee, and Richard Madden. 2016. How colonisation determines social justice and Indigenous health - a review of the literature. Journal of Population Research 33: 9-30. [CrossRef]

Gulati, Ranjay. 1998. Alliances and networks. Strategic Management Journal 19: 293-317. [CrossRef]

Gulati, Ranjay, Tarun Khanna, and Nitin Nohria. 1994. Unilateral commitments and the importance of process in alliances. MIT Sloan Management Review 35: 61.

Harris, Roger, and Anshuman Khare. 2002. Sustainable development issues and strategies for Alberta's oil industry. Technovation 22: 571-83. [CrossRef]

Harvey, David. 2005. A Brief History of Neoliberalism. Oxford: Oxford University Press.

Heide, Jan B. 1994. Interorganizational governance in marketing channels. The Journal of Marketing 58: 71-85. [CrossRef]

Henry, Ella, and Hone Pene. 2001. Kaupapa Maori: Locating Indigenous ontology, epistemology and methodology in the academy. Organization 8: 234-42. [CrossRef]

Hill, Charles W. L. 1990. Cooperation, opportunism, and the invisible hand: Implications for transaction cost theory. Academy of Management Review 15: 500-13. [CrossRef]

Hindle, Kevin, and Peter Moroz. 2010. Indigenous entrepreneurship as a research field: Developing a definitional framework from the emerging canon. International Entrepreneurship and Management Journal 6: 357-85. [CrossRef]

Hindle, Kevin, Robert B. Anderson, Robert J. Giberson, and Bob Kayseas. 2005. Relating practice to theory in Indigenous entrepreneurship: A pilot investigation of the Kitsaki partnership portfolio. The American Indian Quarterly 29: 1-23. [CrossRef]

Himley, Matthew. 2013. Regularizing extraction in Andean Peru: Mining and social mobilization in an age of corporate social responsibility. Antipode 45: 394-416. [CrossRef]

Horowitz, Frances Degen. 2014. Exploring Developmental Theories: Toward a Structural/Behavioral Model of Development. New York: Psychology Press.

Husted, Bryan W. 2003. Governance choices for corporate social responsibility: To contribute, collaborate or internalize? Long Range Planning 36: 481-98. [CrossRef]

Jensen, Michael C., and William H. Meckling. 1976. Theory of the firm: Managerial behavior, agency costs and ownership structure. Journal of Financial Economics 3: 305-60. [CrossRef]

Kang, Charles, Frank Germann, and Rajdeep Grewal. 2016. Washing away your sins? Corporate social responsibility, corporate social irresponsibility, and firm performance. Journal of Marketing 80: 59-79. [CrossRef]

Kayseas, Bob, Bettina Schneider, Raquel Pasap, Moses Gordon, and Robert B. Anderson. 2017. Indigenous rights capital: The basis for sustainable enterprise creation. In Indigenous Aspirations and Rights: The Case for Responsible Business and Management. Edited by Amy Klemm Verbos, Ella Henry and Ana Maria Peredo. New York: Routledge.

Kogut, Bruce. 1988. Joint ventures: Theoretical and empirical perspectives. Strategic Management Journal 9: 319-32. [CrossRef]

Kopka, Kimberly, Lois S. Mahoney, Susan P. Convery, and William LaGore. 2014. An examination of alliances and corporate social responsibility. In Research on Professional Responsibility and Ethics in Accounting. Edited by Cynthia Jeffrey. Bingley: Emerald Group Publishing Limited, pp. 109-30.

Kuhn, Thomas S. 1970. The Structure of Scientific Revolutions. Chicago: University of Chicago Press.

Kytle, Beth, and John Gerard Ruggie. 2005. Corporate Social Responsibility as Risk Management: A Model for Multinationals. Available online: http://hdl.handle.net/123456789/455 (accessed on 21 October 2019).

Laasch, Oliver. 2016. Business Model Change through Embedding Corporate Responsibility-Sustainability? Logics, Devices, Actor Networks. Manchester: University of Manchester.

Langton, Marcia, and Judy Longbottom, eds. 2012. Community Futures, Legal Architecture: Foundations for Indigenous Peoples in the Global Mining Boom. London: Routledge. 
Laumann, Edward O., Joseph Galaskiewicz, and Peter V. Marsden. 1978. Community structure as interorganizational linkages. Annual Review of Sociology 4: 455-84. [CrossRef]

Lawrence, Rebecca, and Rasmus Kløcker Larsen. 2017. The politics of planning: Assessing the impacts of mining on Sami lands. Third World Quarterly 38: 1164-80. [CrossRef]

Le Ber, Marlene J., and Oana Branzei. 2010. Towards a critical theory of value creation in cross-sector partnerships. Organization 17: 599-629. [CrossRef]

Lertzman, David A., and Harrie Vredenburg. 2005. Indigenous peoples, resource extraction and sustainable development: An ethical approach. Journal of Business Ethics 56: 239. [CrossRef]

Levi-Strauss, C. 1962. 'La pens'ee Sauvage. Paris: Librairie Plon, [English translation (1966) The Savage Mind, University of Chicago Press, Chicago, IL].

Liket, Kellie, and Karen Maas. 2016. Strategic philanthropy: Corporate measurement of philanthropic impacts as a requirement for a "happy marriage" of business and society. Business E Society 55: 889-921.

Lin, Haiying, and Nicole Darnall. 2015. Strategic alliance formation and structural configuration. Journal of Business Ethics 127: 549-64. [CrossRef]

Lincoln, Yvonna S., and Egon G. Guba. 2004. The roots of fourth generation evaluation. In Evaluation Roots: Tracing Theorists' Views and Influences. Edited by M. C. Alkin. Thousand Oaks: Sage, pp. 225-41.

Liu, Gordon, Wai Wai Ko, and Chris Chapleo. 2016. How and when socially entrepreneurial nonprofit organizations benefit from adopting social alliance management routines to manage social alliances? Journal of Business Ethics 151: 497-516.

London, Manuel. 2012. CSR partnership initiatives. Organizational Dynamics 3: 220-29. [CrossRef]

Macneil, Ian R. 1974. Restatement Second of Contracts and Presentation. Va. L. Rev. 60: 589-610. [CrossRef]

Macneil, Ian R. 1980. Economic analysis of contractual relations: Its shortfalls and the need for a rich classificatory apparatus. Nw. UL Rev. 75: 1018.

Marens, Richard. 2016. Laying the foundation: Preparing the field of business and society for investigating the relationship between business and inequality. Business \& Society 57: 1252-85.

Margolis, Joshua D., and James P. Walsh. 2003. Misery loves companies: Rethinking social initiatives by business. Administrative Science Quarterly 48: 268-305. [CrossRef]

Matten, Dirk, and Jeremy Moon. 2008. "Implicit" and "explicit" CSR: A conceptual framework for a comparative understanding of corporate social responsibility. Academy of Management Review 33: 404-24. [CrossRef]

McAllister, Daniel J. 1995. Affect-and cognition-based trust as foundations for interpersonal cooperation in organizations. Academy of Management Journal 38: 24-59.

McDonald, Sharyn, and Suzanne Young. 2012. Cross-sector collaboration shaping corporate social responsibility best practice within the mining industry. Journal of Cleaner Production 37: 54-67. [CrossRef]

McEwan, Cheryl, Emma Mawdsley, Glenn Banks, and Regina Scheyvens. 2017. Enrolling the private sector in community development: Magic bullet or slight of hand. Development and Change 48: 28-53. [CrossRef]

McKenna, Kylie. 2015. Corporate security practices and human rights in West Papua. Conflict, Security $\mathcal{E}$ Development 15: 359-85.

Missens, Richard, Leo Paul Dana, and Robert Anderson. 2007. Aboriginal partnerships in Canada: Focus on the Diavik diamond mine. Journal of Enterprising Communities: People and Places in the Global Economy 1: 54-76. [CrossRef]

Moffat, Kieren, Justine Lacey, Airong Zhang, and Sina Leipold. 2016. The social licence to operate: A critical review. Forestry 89: 477-88. [CrossRef]

Moroz, Peter W., Bob Kayseas, and Robert B. Anderson. 2014. Using strategic alliances to facilitate community-based new venture creation. International Journal of Entrepreneurship and Small Business 22: 36-49. [CrossRef]

Nakashima, Douglas, and Marie Roué. 2002. Indigenous knowledge, peoples and sustainable practice. In Encyclopedia of Global Environmental Change. Edited by P. Timmerman. Chichester: John Wiley \& Sons, vol. 5, pp. 314-24.

Nicholson, Amber, Chellie Spiller, and Edwina Pio. 2017. Ambicultural governance: Harmonizing Indigenous and Western approaches. Journal of Management Inquiry 28: 31-47. [CrossRef]

Obalola, Musa, Kamil Omoteso, and Ismail Adelopo. 2016. Corporate Governance and Corporate Social Responsibility Practices in Africa. In Global Perspectives on Corporate Governance and CSR. Edited by G. Aras. London: Routledge. 
O'Faircheallaigh, Ciaran. 2008. Negotiating cultural heritage? Aboriginal-mining company agreements in Australia. Development and Change 39: 25-51. [CrossRef]

O'Faircheallaigh, Ciaran, and Saleem Ali, eds. 2008. Earth Matters: Indigenous Peoples, the Extractive Industries and Corporate Social Responsibility. Sheffield: Greenleaf.

Park, Seung Ho, and Gerardo R. Ungson. 2001. Interfirm rivalry and managerial complexity: A conceptual framework of alliance failure. Organization Science 12: 37-53. [CrossRef]

Penrose, Edith, and Edith Tilton Penrose. 1957. The Theory of the Growth of the Firm. Oxford: Oxford University Press.

Peredo, Ana Maria, and James J. Chrisman. 2006. Toward a theory of community-based enterprise. Academy of Management Review 31: 309-28. [CrossRef]

Peredo, Ana María, Robert B. Anderson, Craig S. Galbraith, Benson Honig, and Leo Paul Dana. 2004. Towards a theory of Indigenous entrepreneurship. International Journal of Entrepreneurship and Small Business 1: 1-20. [CrossRef]

Peredo, Ana Maria, Helen M. Haugh, and Murdith McLean. 2017. Common property: Uncommon forms of prosocial organizing. Journal of Business Venturing, 1-12. [CrossRef]

Pfeffer, Jeffrey, and Gerald R. Salancik. 1978. The External Control of Organizations: A Resource Dependence Approach. Stanford: Stanford University Press.

Piltan, Mehdi, and Taraneh Sowlati. 2014. A review of partnership studies in the forests products value chain: With a focus on developed countries. Forest Products Journal 64: 4-10. [CrossRef]

Pirson, Michael. 2017. Humanistic Management: Protecting Dignity and Promoting Well-Being. Cambridge: Cambridge University Press.

Polanyi, Karl. 1944. The Great Transformation: Economic and Political Origins of Our Time. New York: Ferrar \& Rinehart.

Porter, Michael E. 1980. Competitive Strategy: Techniques for Analyzing Industries. New York: Free Press.

Porter, Michael E. 1985. Technology and competitive advantage. Journal of Business Strategy 5: 60-78. [CrossRef]

Porter, Michael E., and Mark R. Kramer. 2011. The Big Idea: Creating Shared Value. How to reinvent capitalism—and unleash a wave of innovation and growth. Harvard Business Review 89: 2.

Powell, E. Erin, Ralph Hamann, Verena Bitzer, and Ted Baker. 2017. Bringing the elephant into the room? Enacting conflict in collective prosocial organizing. Journal of Business Venturing 33: 623-42. [CrossRef]

Quélin, Bertrand V., Ilze Kivleniece, and Sergio Lazzarini. 2017. Public-private collaboration, hybridity and social value: Towards new theoretical perspectives. Journal of Management Studies 54: 763-92. [CrossRef]

Ramanathan, Kannan, Anju Seth, and Howard Thomas. 1997. Explaining joint ventures: Alternative theoretical perspectives. Cooperative Strategies 1: 51-85.

Rawhouser, Hans, Michael Cummings, and Andrew Crane. 2015. Benefit corporation legislation and the emergence of a social hybrid category. California Management Review 57: 13-35. [CrossRef]

Richards, Claire, Mary Ann Reynolds, and Jesse Dillard. 2016. Governance and reporting in a complex global environment. Universal Journal of Accounting and Finance 4: 1-8. [CrossRef]

Ridley-Duff, Rory, and Mike Bull. 2011. Understanding Social Enterprise: Theory and Practice. London: Sage Publications.

Rost, Katja, and Thomas Ehrmann. 2015. Reporting biases in empirical management research: The example of win-win corporate social responsibility. Business \& Society 56: 840-88.

Rousseau, Denise M., and Yitzhak Fried. 2001. Location, location, location: Contextualizing organizational research. Journal of Organizational Behavior 22: 1-13. [CrossRef]

Runge, Carlisle Ford. 1986. Common property and collective action in economic development. World Development 14: 623-35. [CrossRef]

Ruwhiu, Diane, and Lynette Carter. 2016. Negotiating "meaningful participation" for Indigenous peoples in the context of mining. Corporate Governance 16: 641-54.

Ryan, Richard M., and Edward L. Deci. 2000. Self-determination theory and the facilitation of intrinsic motivation, social development, and well-being. American Psychologist 55: 68. [CrossRef]

Sabeti, Heerad. 2011. The for-benefit enterprise. Harvard Business Review 89: 98-104.

Sahlins, Marshall. 1972. Stone Age Economics. Chicago: Aldine.

Sawyer, Suzana, and Edmund Terence Gomez. 2012. The Politics of Resource Extraction: Indigenous Peoples, Multinational Corporations, and the State. New York: Palgrave Macmillan. 
Schlager, Edella, and Elinor Ostrom. 1992. Property rights regimes and natural resources: A conceptual analysis. Land Economics 68: 249-62. [CrossRef]

Schminke, Marshall, and Deborah Wells. 1999. Group processes and performance and their effects on individuals' ethical frameworks. Journal of Business Ethics 18: 367-81. [CrossRef]

Senevirathna, Priyan. 2018. Creating shared value through partnerships in agricultural production in Sri Lanka. Geoforum 90: 219-22. [CrossRef]

Shepherd, Dean A., and Holger Patzelt. 2011. The new field of sustainable entrepreneurship: Studying entrepreneurial action linking "what is to be sustained" with "what is to be developed". Entrepreneurship Theory and Practice 35: 137-63. [CrossRef]

Short, Jeremy C., Aaron F. McKenny, David J. Ketchen, Charles C. Snow, and G. Tomas M. Hult. 2016. An empirical examination of firm, industry, and temporal effects on corporate social performance. Business $\mathcal{E}$ Society 55: 1122-56.

Sloan, Pamela, and David Oliver. 2013. Building trust in multi-stakeholder partnerships: Critical emotional incidents and practices of engagement. Organization Studies 34: 1835-68. [CrossRef]

Stiglitz, Joseph E. 2002. Participation and development: Perspectives from the comprehensive development paradigm. Review of Development Economics 6: 163-82. [CrossRef]

Stiles, Jan. 2001. Managing strategic alliances success: Determining the influence factors of intent within partnerships. In Effective Collaboration: Managing the Obstacles to Success. Edited by Frank McDonald and Jens Genefke. Basingstoke: Palgrave, pp. 17-43.

Suddaby, Roy, and Royston Greenwood. 2005. Rhetorical strategies of legitimacy. Administrative Science Quarterly 50: 35-67. [CrossRef]

Sukhdev, Pavan. 2012. Corporation 2020. Washington: Island Press.

Swanson, Lee A., and David D. Zhang. 2015. The base requirements, community, and regional levels of northern development. Northern Review 38: 199-222.

Swinney, Jane. 2008. Sponsorship, community, and social capital resources in indigenous communities. Journal of Developmental Entrepreneurship 13: 363-79. [CrossRef]

Tavanti, Marco, Molly Brennan, and Shelly Helgeson. 2017. Management education for sustainable development: Integrating ecology and community values in social impact practicums. Journal of Management for Global Sustainability 4: 75-99. [CrossRef]

Thorne, Linda, Lois S. Mahoney, Kristen Gregory, and Susan Convery. 2017. A comparison of Canadian and US CSR strategic alliances, CSR reporting, and CSR performance: Insights into implicit-explicit CSR. Journal of Business Ethics 143: 85-98. [CrossRef]

Tickell, Adam, and Jamie A. Peck. 1996. Social regulation after Fordism: Regulation theory, neo-liberalism and the global-local nexus. Economy and Society 24: 357-86. [CrossRef]

Tranfield, David, David Denyer, and Palminder Smart. 2003. Towards a methodology for developing evidence-informed management knowledge by means of systematic review. British Journal of Management 14: 207-22. [CrossRef]

Vaidya, Sameer. 2011. Understanding strategic alliances: An integrated framework. Journal of Management Policy and Practice 12: 90-100.

Van Wijk, Raymond, Justin JP Jansen, and Marjorie A. Lyles. 2008. Inter-and intra-organizational knowledge transfer: A meta-analytic review and assessment of its antecedents and consequences. Journal of Management Studies 45: 830-53. [CrossRef]

Wang, Qian, Junsheng Dou, and Shenghua Jia. 2016. A meta-analytic review of corporate social responsibility and corporate financial performance: The moderating effect of contextual factors. Business $\mathcal{E}$ Society 55: 1083-121.

Warner, Michael, and Rory Sullivan. 2017. Putting Partnerships to Work: Strategic Alliances for Development between Government, the Private Sector and Civil Society. London: Routledge.

Whetten, David A. 2009. An examination of the interface between context and theory applied to the study of Chinese organizations. Management and Organization Review 5: 29-55. [CrossRef]

Whiteman, Gail, Brian Walker, and Paolo Perego. 2013. Planetary boundaries: Ecological foundations for corporate sustainability. Journal of Management Studies 50: 307-36. [CrossRef]

Wickert, Christopher, Andreas Georg Scherer, and Laura J. Spence. 2016. Walking and talking corporate social responsibility: Implications of firm size and organizational cost. Journal of Management Studies 53: 1169-96. [CrossRef] 
Williamson, Oliver E. 1975. Markets and hierarchies: Some elementary considerations. In Strategy: Critical Perspectives on Business and Management. Edited by David Faulkner. New York: Routledge, vol. 4, pp. 106-18. Williamson, Oliver E. 1985. The Economic Institutions of Capitalism: Firms, Markets, Relational Contracting. New York: Free Press.

Wyatt, Stephen. 2008. First Nations, forest lands, and "aboriginal forestry" in Canada: From exclusion to comanagement and beyond. Canadian Journal of Forest Research 38: 171-80. [CrossRef]

(c) (C) 2020 by the authors. Licensee MDPI, Basel, Switzerland. This article is an open access article distributed under the terms and conditions of the Creative Commons Attribution (CC BY) license (http://creativecommons.org/licenses/by/4.0/). 